\title{
Impacts of near-future cultivation of biofuel feedstocks on atmospheric composition and local air quality
}

\author{
K. Ashworth ${ }^{1}$, G. Folberth ${ }^{2}$, C. N. Hewitt ${ }^{1}$, and O. Wild ${ }^{1}$ \\ ${ }^{1}$ Lancaster Environment Centre, Lancaster University, Lancashire LA1 4YQ, UK \\ ${ }^{2}$ Met Office Hadley Centre, Exeter, EX1 3PB, UK \\ Correspondence to: O. Wild (o.wild@lancaster.ac.uk)
}

Received: 29 July 2011 - Published in Atmos. Chem. Phys. Discuss.: 5 September 2011

Revised: 6 January 2012 - Accepted: 10 January 2012 - Published: 19 January 2012

\begin{abstract}
Large-scale production of feedstock crops for biofuels will lead to land use changes. We quantify the effects of realistic land use change scenarios for biofuel feedstock production on isoprene emissions and hence atmospheric composition and chemistry using the HadGEM 2 model. Two feedstocks are considered: oil palm for biodiesel in the tropics and short rotation coppice (SRC) in the mid-latitudes. In total, 69 Mha of oil palm and 92 Mha of SRC are planted, each sufficient to replace just over $1 \%$ of projected global fossil fuel demand in 2020. Both planting scenarios result in increases in total global annual isoprene emissions of about $1 \%$. In each case, changes in surface concentrations of ozone and biogenic secondary organic aerosol (bSOA) are substantial at the regional scale, with implications for air quality standards. However, the changes in tropospheric burden of ozone and the $\mathrm{OH}$ radical, and hence effects on global climate, are negligible. Over SE Asia, one region of oil palm planting, increases in annual mean surface ozone and bSOA concentrations reach over $3 \mathrm{ppbv}(+11 \%)$ and $0.4 \mu \mathrm{gm}^{-3}$ $(+10 \%)$ respectively for parts of Borneo, with monthly mean increases of up to $6.5 \mathrm{ppbv}(+25 \%)$ and $0.5 \mu \mathrm{g} \mathrm{m}^{-3}(+12 \%)$. Under the SRC scenario, Europe experiences monthly mean changes of over $0.6 \mathrm{ppbv}(+1 \%)$ and $0.1 \mu \mathrm{g} \mathrm{m}^{-3}(+5 \%)$ in June and July, with peak increases of over 2 ppbv $(+3 \%)$ and $0.5 \mu \mathrm{g} \mathrm{m}^{-3}(+8 \%)$. That appreciable regional atmospheric impacts result from low level planting scenarios demonstrates the need to include changes in emissions of reactive trace gases such as isoprene in life cycle assessments performed on potential biofuel feedstocks.
\end{abstract}

\section{Introduction}

The formation of tropospheric ozone and aerosol particles has both climate and air quality implications. Ozone is an important greenhouse gas (Forster et al., 2007) and is detrimental to human, animal and plant health (Royal Society, 2008). Particulate matter has been identified as a major cause of ill-health and premature death around the world (WHO, 2005). Aerosols also have a cooling effect on the climate, although the magnitude of their forcing is not known with much certainty (Forster et al., 2007).

Volatile organic compounds (VOCs) are a major precursor of both ozone and secondary organic aerosol (SOA) in the troposphere. The biosphere is the largest source of VOCs; it is estimated that around $1150 \mathrm{TgCyr}^{-1}$ of VOCs are emitted by vegetation (Guenther et al., 1995), compared with $130 \mathrm{TgCyr}^{-1}$ contributed by anthropogenic sources (Lamarque et al., 2010). Furthermore, biogenic emissions are dominated by isoprene $\left(\mathrm{C}_{5} \mathrm{H}_{8}\right)$, with an estimated flux of $500 \mathrm{TgCyr}^{-1}$ (e.g. Guenther et al., 2006; Arneth et al., 2008). Given the high reactivity of isoprene and its oxidation products (Atkinson and Arey, 2003), changes in the flux of isoprene may have a significant impact on the composition of the troposphere, and in particular, ozone and aerosol particles.

Isoprene emission rates vary according to plant species and foliage density, and are further modified by the growing conditions, increasing strongly with temperature and photosynthetically active radiation (e.g. Guenther et al., 1995; Simpson et al., 1995; Arneth et al., 2007). Thus, global vegetation distribution is a key factor in determining not only the total isoprene flux from the biosphere but also its spatial 
and temporal fluctuations (e.g. Guenther et al., 2006; Arneth et al., 2007, 2011). Changes in land use and land cover will play an important part in governing future isoprene emissions and hence atmospheric composition and air quality.

\subsection{Biofuels}

One important driver of land use change (LUC) in the near future is the projected increase in demand for biofuels for heat or power production and transportation (e.g. Royal Society, 2008). This study considers biofuels for transportation: biodiesel and so-called "second-generation" bioethanol from lignocellulose (Royal Society, 2008). In 2005, the global production of biofuels was sufficient to replace about $1 \%$ of global transportation fuel (IEA, 2006). The demand for such biofuels is expected to increase strongly though, driven by government policies such as the commitment to replace $10 \%$ of diesel and gasoline in the EU with biofuels by 2020 (EC, 2008), the target of $20 \%$ biodiesel use in Indonesia by 2025 (Zhou and Thomson, 2009), the aim to replace $30 \%$ of the 2004 gasoline use in the USA with lignocellulosic ethanol by 2030 (Perlack et al., 2005). This demand is expected to be met, as now, through the use of dedicated feedstock crops (such as corn, sugarcane, rapeseed and oil palm), grown either on land currently used for agriculture (e.g. Searchinger et al., 2008; Bartle and Abadi, 2010) or on deforested land (e.g. Fargione et al., 2008; Koh et al., 2009), although there are proposals to use abandoned and marginal land for some feedstock crops (e.g. Fischer et al., 2010; Campbell et al., 2008).

Life cycle assessments of biofuels attempt to quantify the net environmental impact of replacing fossil fuel production and use with that of a specific biofuel, but generally only compare the energy requirements and direct greenhouse gas emissions (e.g., Ou et al., 2009). More recently, this approach has been extended to include the impact of converting land to biofuel cultivation, for example through forest clearance (e.g., Fargione et al., 2008). However, full "seedto-wheels" assessments are still uncommon (e.g. Menichetti and Otto, 2009) and there is no agreed method of including indirect land use impacts (e.g. Melillo et al., 2009). Furthermore, the effects of altering the magnitude or spatial distribution of bVOC emissions through such LUC have not been included in these assessments.

\section{2 bVOCs and LUC}

Previous studies considering the impact of changing land cover on the emissions of biogenic VOCs have either taken the form of sensitivity studies involving widespread land use change (e.g. complete tropical deforestation, Lathière et al., 2006; Wiedinmyer et al., 2006; Pyle et al., 2011), or have been based on the IPCC SRES A2 scenario (Nakicenovic and Swart, 2000) that projects the greatest land use change (see e.g. Heald et al., 2008; Chen et al., 2009; Ganzeveld et al., 2010).

Global modelling studies of LUC consistent with the A2 scenario show similar results, with isoprene emissions projected to decrease by up to $15 \%$ on a global basis (Heald et al., 2008; Ganzeveld et al., 2010), although there are substantial regional variations, with Chen et al. (2009) simulating decreases of up to $52 \%$ for the NW USA.

Lathière et al. (2006) found tropical deforestation decreased global isoprene emissions by over $25 \%$, while Wiedinmyer et al. (2006) showed that partial deforestation of the SE USA and the Amazon resulted in a decrease of just $9 \%$ in global emissions. Lathière et al. (2006) and Wiedinmyer et al. (2006) also considered scenarios leading to increases in isoprene emissions: European afforestation and biofuel plantations in western USA and the Amazon respectively. Lathière et al. (2006) found that replacing all crops and grasses in Europe with deciduous trees increased European isoprene emissions by over $120 \%$, although the global impact was small ( $\sim 4 \%$ increase). Wiedinmyer et al. (2006) reported a global increase in isoprene emissions of nearly $40 \%$ due to large-scale planting of poplar and eucalyptus.

The impacts of the changes in bVOC emissions on atmospheric composition were considered by several of these studies. Wiedinmyer et al. (2006) found that while groundlevel ozone concentrations in the region of the LUC changed by as much as $10 \mathrm{ppbv}$, the global ozone burden was barely affected. Ganzeveld et al. (2010) found that even on a regional basis, the competing effects of changes in bVOC emissions, deposition and climate resulted in negligible changes in ozone. By contrast, Chen et al. (2009) showed that groundlevel ozone concentrations increased in spite of the decrease in isoprene emissions, due to increasing anthropogenic emissions under the A2 scenario. Both Heald et al. (2008) and Chen et al. (2009) found that biogenic SOA burdens were most affected by changes in monoterpene emission rates, and fell almost proportionally in response to such changes.

The work presented here extends previous studies of the environmental implications of biofuels, focusing on the atmospheric impacts of altering isoprene emissions by replacing current vegetation with two types of biofuel feedstock crops: oil palm and short rotation coppice (fast-growing tree species that are harvested every two to three years for their biomass). In contrast to previous work on bVOC emissions outlined above, the scenarios used represent realistic low density planting for near-future biofuel production, based on current government pledges. The scope of the study does not extend to the initial land clearance, nor the end use (combustion) of the biofuel. We focus on changes in isoprene only, as these biofuel feedstocks are strong isoprene emitters. 
Table 1. Overview of simulations.

\begin{tabular}{lccccc}
\hline Simulation & $\begin{array}{c}\text { Biofuel } \\
\text { feedstock }\end{array}$ & Fuel type & $\begin{array}{c}\text { Location of } \\
\text { cultivation }\end{array}$ & $\begin{array}{c}\text { Cultivated } \\
\text { area }(\mathrm{Mha})\end{array}$ & $\begin{array}{c}\text { Fuel yield } \\
\text { (Mt yr }\end{array}$ \\
\hline CTRL & - & - & - & - & - \\
PALM & Oil palm & Biodiesel & Tropics & 69 & 200 \\
PALM_NO & Oil palm & Biodiesel & Tropics & 69 & 200 \\
SRC & $\begin{array}{c}\text { Short rotation } \\
\text { coppice }\end{array}$ & $\begin{array}{c}\text { Ligno-cellulosic } \\
\text { ethanol }\end{array}$ & Mid-latitudes & 92 & 150 \\
\hline
\end{tabular}

\section{Model approach}

This study was performed with the UK Met Office Hadley Centre's Earth system model, HadGEM2, with model resolution, boundary and initial conditions set as for the IPCC AR5 Climate Model Intercomparison Project (CMIP5) runs (Jones et al., 2011). In this study, HadGEM2 was run in its climate configuration, so the full Earth system couplings were not applied -specifically, changes in atmospheric composition (surface concentrations of ozone and SOA) arising from the changes in biogenic emissions do not affect either primary productivity or biogenic emissions. The extended chemistry version of the UK Community Chemistry and Aerosol (UKCA) scheme applied in HadGEM2 features roughly 300 reactions and 83 species, and includes simplified isoprene reactions (Folberth et al., 2006) based on those of the Mainz Isoprene Mechanism (Pöschl et al., 2000). SOA is formed from isoprene and monoterpenes using the twoproduct approach, following the methodology outlined by Derwent et al. (2003). This results in a molar yield of around $3 \%$ of SOA from isoprene and $13 \%$ from monoterpenes (Mann et al., 2010). HadGEM2 was run at $1.9^{\circ}$ by $1.3^{\circ}$ resolution using a present-day climate derived from decadal average monthly mean sea surface temperatures and sea-ice fields for 2001-2010 taken from the CMIP5 simulations. Simulations were run for two years following a four month spin-up period and the first year discarded. We used anthropogenic emissions for 2005 (Lamarque et al., 2010). Biogenic emissions of isoprene, a lumped monoterpene species, acetone and methanol are calculated on-line by the iBVOC emissions model; the isoprene emissions scheme is described by Pacifico et al. (2011). The decadal average vegetation distribution for 2001-2010 taken from the CMIP5 bicentennial simulation, which features fully interactive dynamic vegetation (Jones et al., 2011), was used to represent the current vegetation (i.e. the vegetation without additional biofuel feedstock crops).

Three experiments were carried out, in addition to the control run (CTRL) described above that is assumed to account for all existing biofuel cultivation, to assess the impact of additional planting of single biofuel crop types on atmospheric composition and air quality. In these experiments, only isoprene emissions were altered to reflect the planting changes; all other model settings were unchanged. The impacts of other factors, e.g. the changes to ozone deposition rates and the direct climate effects of deforestation, are considered in Sects. 5 and 6 . Table 1 provides an overview of the simulations.

Two distinct biofuel scenarios have been developed for use in this study, representing potential biofuel crop locations and species in the $2020 \mathrm{~s}$, based on current government pledges. The scale of the changes is subtle but provides a realistic framework for this investigation. The first, based on the cultivation of oil palm for conversion to palm oil for blending with diesel, is used in two simulations (PALM and PALM_NO $\mathrm{NO}_{\mathrm{x}}$ ). The third experiment investigates the impact of inter-planting current agricultural crops in the midlatitudes with fast-growing tree species, referred to as short rotation coppice (SRC).

\subsection{Oil palm scenarios}

A total of 69 Mha of natural rainforest - 29 Mha in South and Central America (Koh et al., 2009; da Costa, 2004), 13 Mha in Africa (Koh et al., 2009) and 27 Mha in SE Asia (Abdullah et al., 2009; Koh et al., 2009; USDA, 2009; Zhou and Thomson, 2009) - was replaced by oil palm plantations, a four-fold increase in the current area of such plantations (Thoenes, 2007). The locations of planting reflect either specific near- future projects or an expansion of existing cultivation. Depending on the fuel yield achieved, these scenarios produce sufficient biodiesel to replace $1-2 \%$ of the world's projected fossil fuel demand in 2020 (Energy Information Agency, 2010).

Although tropical broad-leaved trees are substantial emitters of isoprene (e.g. Guenther et al., 2006), emissions from oil palm trees are exceptionally high; the recent OP3 field campaign in Borneo found isoprene fluxes from an oil palm plantation to be as much as 7 times higher than those from neighbouring rainforest (Hewitt et al., 2010). Isoprene emissions from the identified locations are scaled in HadGEM2 prior to their input to the chemistry module, UKCA. The methodology and emission factors used for this scaling are given in Appendix A1. The underlying vegetation characteristics (e.g. surface roughness, canopy height, etc.) are 
not altered. For the first experiment, PALM, this is the only change from CTRL.

The second oil palm scenario (PALM_NO ${ }_{x}$ ) uses the same planting but introduces additional $\mathrm{NO}_{\mathrm{x}}$ emissions due to the processing of the oil palm fruit into biodiesel and fertiliser application. These are assumed to be co-located with the new plantations as the fruit must be processed within a few hours of picking (Pleanjai and Gheewala, 2009).

Processing emissions $\left(1.5 \mathrm{~kg}(\mathrm{NO}) \mathrm{ha}^{-1} \mathrm{y}^{-1}\right)$ were calculated from the energy requirements for oil palm processing detailed by Reijnders and Huijbregts (2008), with emission factors for energy production from Streets et al. (2003), based on the assumption that $100 \%$ of the energy required was produced from plantation waste. $\mathrm{NO}_{\mathrm{x}}$ emissions from fertiliser applications $\left(1.9 \mathrm{~kg}(\mathrm{NO}) \mathrm{ha}^{-1} \mathrm{y}^{-1}\right)$ were deduced from flux measurements made during the OP3 field campaigns in Borneo (Hewitt et al., 2009). Both processing and fertiliser emissions are assumed to be constant throughout the year, and a simple time profile applied to give higher emissions during the day and low emissions at night.

\subsection{Short rotation coppice (SRC) scenario}

This scenario also involves substantial increases in isoprene emissions in the affected areas as non-emitting crops are replaced with broad-leaf tree species (typically poplar, willow or eucalyptus). A total of $92 \mathrm{Mha}$ of SRC are planted in current agricultural or abandoned areas in the continental US (18 Mha - Perlack et al., 2005), Europe (70 Mha - Fischer et al., 2010) and Australia (4 Mha - Bartle and Abadi (2010)). This represents about $6 \%$ of agricultural land in the northern mid-latitudes, or about $1.5 \%$ of global agricultural land (including pasture). This scenario is projected to replace just over $1 \%$ of the projected global fossil fuel demand in 2020 (Energy Information Agency, 2010), based on an assumed yield of $0.34 \mathrm{~L}$ (ethanol) $/ \mathrm{kg}$ (biomass) (Hill et al., 2009).

Isoprene emissions from the replaced crops and pasture land, both represented as grasses in HadGEM2, have been scaled to reflect the higher emissions from the SRC species used, as shown in Appendix A1. In Australia, all SRC are assumed to be mallee, a native species of eucalyptus; in the US, all are poplar; in Europe, willow is planted north of $50^{\circ} \mathrm{N}$, eucalyptus south of $40^{\circ} \mathrm{N}$, and poplar in between.

As in the oil palm scenarios, no changes are made to the underlying vegetation distribution in HadGEM2, and the effects of this are discussed in Sects. 5 and 6. Additional $\mathrm{NO}_{\mathrm{x}}$ emissions due to fertiliser application and biofuel processing were not included in the SRC scenario, as fertiliser application rates to SRC (Hill et al., 2009) are similar to those for agricultural crops in the mid-latitudes (FAO, 2006), and no data is available for large-scale processing of SRC to lignocellulosic ethanol. The mid-latitudes are also, for the most part, a relatively high- $\mathrm{NO}_{\mathrm{x}}$ environment, so the impact of additional small emissions of $\mathrm{NO}_{\mathrm{x}}$ are likely to be slight.

\subsection{Comparison of scenarios}

Both biofuel crops lead to similar increases in isoprene emissions, but differences in the distribution of emissions in the two scenarios affect the formation of ozone and secondary organic aerosols. Atmospheric oxidation of isoprene and other VOCs are governed by the availability of the $\mathrm{OH}$ radical, ozone and the $\mathrm{NO}_{3}$ radical. In this study, planting in the tropics mainly occurs in clean, low- $\mathrm{NO}_{\mathrm{x}}$ environments, where the VOC: $\mathrm{NO}_{\mathrm{x}}$ ratio is high and ozone production is "NO ${ }_{\mathrm{x}}$-sensitive" (Sillman, 1999). In such regions, an increase in isoprene emissions is likely to result in a net loss of ozone, either through ozonolysis of isoprene or by enhancing $\mathrm{O}_{3}$ loss more than $\mathrm{O}_{3}$ production. In the high- $\mathrm{NO}_{\mathrm{x}}$ northern mid-latitudes, most areas have low VOC: $\mathrm{NO}_{\mathrm{x}}$ ratios and can be described as "VOC-sensitive" (Sillman, 1999) at the surface. Increased isoprene emissions in such areas typically favour increased ozone formation.

Increased isoprene emissions are also likely to result in increases in SOA formation. Although isoprene oxidation is not the dominant source of SOA on a per-molecule basis, its high emission rate results in a considerable total yield of SOA, so changes in isoprene emissions would be expected to be reflected in SOA concentration (see e.g. Tsigaridis and Kanakidou, 2007). As well as the direct increase in SOA from isoprene and its reaction products, higher isoprene concentrations result in higher yields of SOA from monoterpenes in the model, due to increased competition for $\mathrm{OH}$. However, it should be noted that recent studies suggest that high levels of isoprene may actually inhibit formation of SOA from monoterpenes (see e.g. Kiendler-Scharr et al., 2009).

\section{Results for oil palm scenarios}

The additional oil palm plantations in these scenarios increase global annual isoprene emissions by just over $1 \%$. The impacts on global tropospheric burdens are very small (of the order of a few tenths of $1 \%$ for ozone and the $\mathrm{OH}$ radical) in both PALM and PALM $\mathrm{NO}_{\mathrm{x}}$ suggesting that the atmospheric lifetime of methane is little affected. Table 2 shows the changes in ground-level ozone and bSOA concentrations globally and in the regions of oil palm planting under the two scenarios. Again, the absolute changes are small on a global scale. However, there are substantial increases on a local scale. Hence, the effect of the small-scale LUC in the oil palm scenarios is limited to local to regional scale changes in atmospheric composition and air quality, rather than global climate.

Changes in atmospheric composition in response to the increase in isoprene emissions are similar in each of the replanted regions. Generally, under the PALM scenario isoprene mixing ratios increase and surface ozone concentrations are reduced in the immediate vicinity of the additional 
Table 2. Summary of changes in ground-level ozone and biogenic SOA concentrations for the oil palm scenarios.

\begin{tabular}{|c|c|c|c|c|}
\hline & $\begin{array}{l}\text { Ozone (ppbv) } \\
\text { PALM }\end{array}$ & $\begin{array}{l}\text { Ozone (ppbv) } \\
\text { PALM_NO }\end{array}$ & $\begin{array}{c}\text { bSOA }\left(\mu g^{-3}\right) \\
\text { PALM }\end{array}$ & $\begin{array}{c}\operatorname{bSOA}\left(\mu \mathrm{gm}^{-3}\right) \\
\text { PALM_NO} \\
\end{array}$ \\
\hline \multicolumn{5}{|l|}{ Global: } \\
\hline Annual mean & $<+0.01[<1 \%]$ & $+0.04[<1 \%]$ & $<+0.01[<1 \%]$ & $<+0.01[<1 \%]$ \\
\hline \multicolumn{5}{|l|}{ SE Asia ${ }^{a}$ : } \\
\hline Annual mean ${ }^{b}$ & $-0.07[<1 \%]$ & $+0.18[<1 \%]$ & $+0.01[2 \%]$ & $+0.02[2 \%]$ \\
\hline Max monthly mean ${ }^{\mathrm{b}}$ & $-0.11[<1 \%]$ & $+0.22[<1 \%]$ & $+0.02[2 \%]$ & $+0.02[2 \%]$ \\
\hline Peak annual mean ${ }^{\mathrm{c}}$ & $-1.64[6 \%]$ & $+3.46[11 \%]$ & $+0.26[6 \%]$ & $+0.39[10 \%]$ \\
\hline Peak monthly mean ${ }^{\mathrm{c}}$ & $-2.72[8 \%]$ & $+6.59[25 \%]$ & $+0.37[7 \%]$ & $+0.53[12 \%]$ \\
\hline \multicolumn{5}{|l|}{ S America ${ }^{\mathrm{d}}$ : } \\
\hline Annual mean ${ }^{\mathrm{b}}$ & $-0.07[<1 \%]$ & $+0.12[<1 \%]$ & $+0.01[<1 \%]$ & $+0.03[<1 \%]$ \\
\hline Max monthly mean ${ }^{b}$ & $-0.13[<1 \%]$ & $+0.15[<1 \%]$ & $+0.02[<1 \%]$ & $+0.03[<1 \%]$ \\
\hline Peak annual mean ${ }^{c}$ & $-1.31[8 \%]$ & $+1.42[8 \%]$ & $+0.09[2 \%]$ & $+0.38[8 \%]$ \\
\hline Peak monthly mean ${ }^{\mathrm{c}}$ & $-3.67[10 \%]$ & $+2.59[29 \%]$ & $+0.35[6 \%]$ & $+0.60[11 \%]$ \\
\hline \multicolumn{5}{|l|}{ Africa ${ }^{\mathrm{e}}$ : } \\
\hline Annual mean ${ }^{\mathrm{b}}$ & $<-0.01[<1 \%]$ & $+0.08[<1 \%]$ & $<+0.01[<1 \%]$ & $<+0.01[<1 \%]$ \\
\hline Max monthly mean ${ }^{\mathrm{b}}$ & $-0.03[<1 \%]$ & $+0.09[<1 \%]$ & $+0.01[<1 \%]$ & $+0.01[<1 \%]$ \\
\hline \multicolumn{5}{|l|}{ Central Africa } \\
\hline Peak annual mean ${ }^{c}$ & $-1.64[6 \%]$ & $-0.19[<1 \%]$ & $+0.17[3 \%]$ & $+0.26[5 \%]$ \\
\hline Peak monthly mean ${ }^{\mathrm{c}}$ & $-2.84[6 \%]$ & $-1.81[4 \%]$ & $+0.32[4 \%]$ & $+0.37[5 \%]$ \\
\hline \multicolumn{5}{|l|}{ Niger Delta } \\
\hline Peak annual mean ${ }^{c}$ & $+0.21[<1 \%]$ & $+0.45[1 \%]$ & $+0.14[5 \%]$ & $+0.13[5 \%]$ \\
\hline Peak monthly mean ${ }^{\mathrm{c}}$ & $+0.48[<1 \%]$ & $+0.90[1 \%]$ & $+0.26[7 \%]$ & $+0.24[6 \%]$ \\
\hline
\end{tabular}

${ }^{\text {a }} \mathrm{SE}$ Asia domain taken as $91.0^{\circ} \mathrm{E}, 10.6^{\circ} \mathrm{S}$ to $130.3^{\circ} \mathrm{E}, 14.4^{\circ} \mathrm{N}$.

$\mathrm{b}$ Values given are the area weighted average change calculated across the stated domain, i.e. SE Asia or S America.

$\mathrm{c}$ Values given are the maximum change in any individual gridbox in the stated domain.

${ }^{\mathrm{d}} \mathrm{S}$ America domain taken as $75.9^{\circ} \mathrm{W},-18.1^{\circ} \mathrm{S}$ to $42.2^{\circ} \mathrm{W}, 9.4^{\circ} \mathrm{N}$.

e Africa domain taken as $10.3^{\circ} \mathrm{W},-8.1^{\circ} \mathrm{S}$ to $28.7^{\circ} \mathrm{E}, 18.1^{\circ} \mathrm{N}$.

The domains were selected to give roughly the same total area

plantations, as expected in a low- $\mathrm{NO}_{\mathrm{x}}$ environment where the increase in destruction of ozone through direct reaction with isoprene dominates. When co-located $\mathrm{NO}_{\mathrm{x}}$ processing emissions are included in the PALM $\_\mathrm{NO}_{\mathrm{x}}$ scenario, the areas around the plantations are no longer $\mathrm{NO}_{\mathrm{x}}$-limited and ozone is generally formed in response to the increased VOC mixing ratios. This is now considered in more detail for each of the regions of land use change.

\subsection{SE Asia}

This region is characterised by sharp contrasts between highly polluted urban areas and primary and secondary growth rainforests. Its geography leads to a strong marine influence on both its climate and atmospheric composition. The region experiences distinct seasonal changes in wind direction, with monsoon north-easterlies dominating between October and March (strongest between November and Jan- uary) and south-westerlies prevailing through the remainder of the year. The reversal of wind direction between the seasons is evident in the figures for January and July shown in Fig. 1.

Annual isoprene emissions from SE Asia increase by about $5 \%$ (from 41 to $43 \mathrm{Tgy}^{-1}$ ) as a result of our oil palm plantations. Monthly mean emissions vary by no more than $10 \%$ from the annual mean in this region, leading to similar mixing ratios throughout the year. All of the short-lived species show a similar non-seasonal response. For compounds with longer atmospheric lifetimes, transport occurs following the prevailing winds, and the magnitude of the response varies according to the origin of the air mass. The area-weighted changes in ground-level ozone and bSOA concentrations over this region are given in Table 2, while Fig. 1 shows the spatial distribution of the changes in monthly mean concentrations for January and July. 
PALM

January
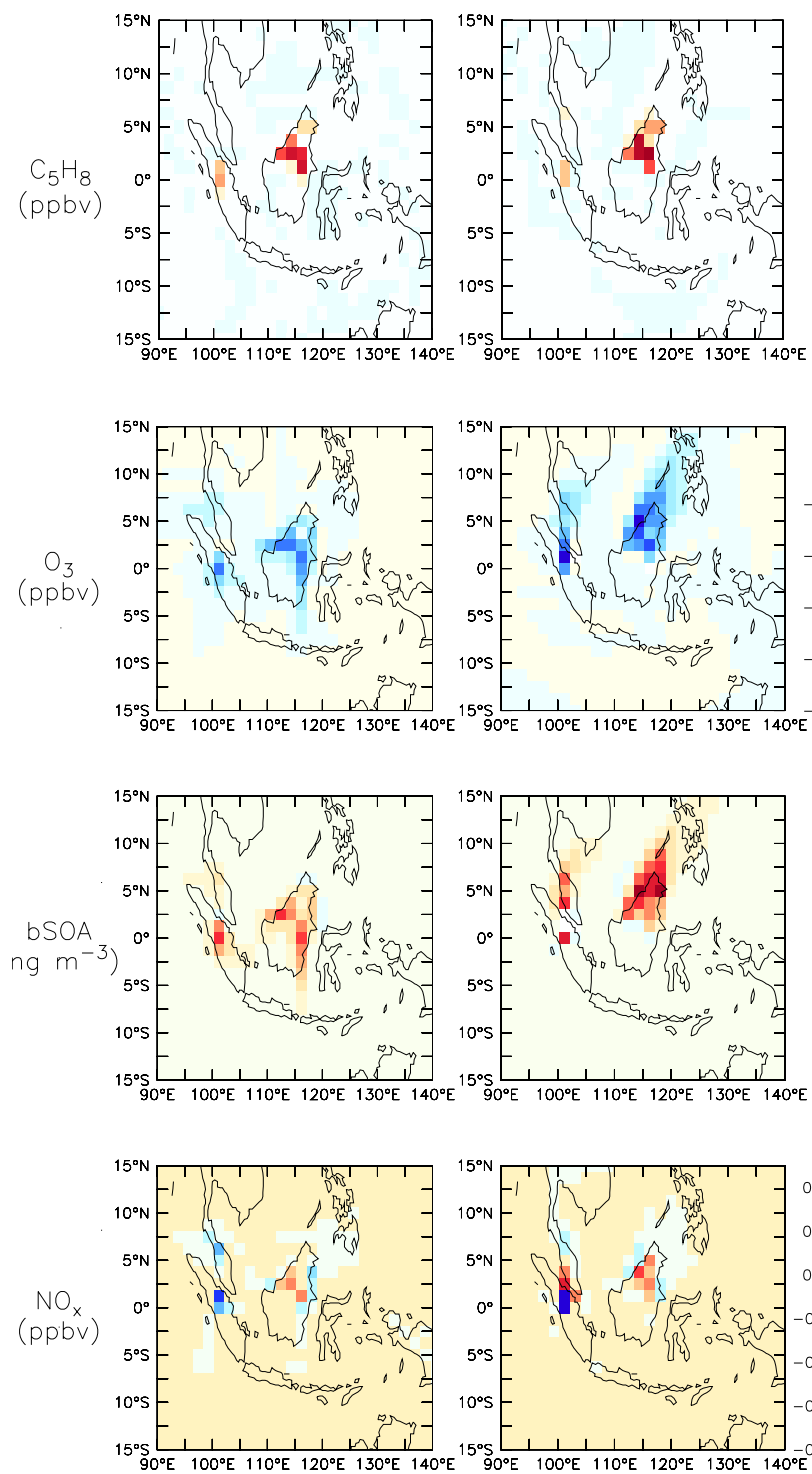

July
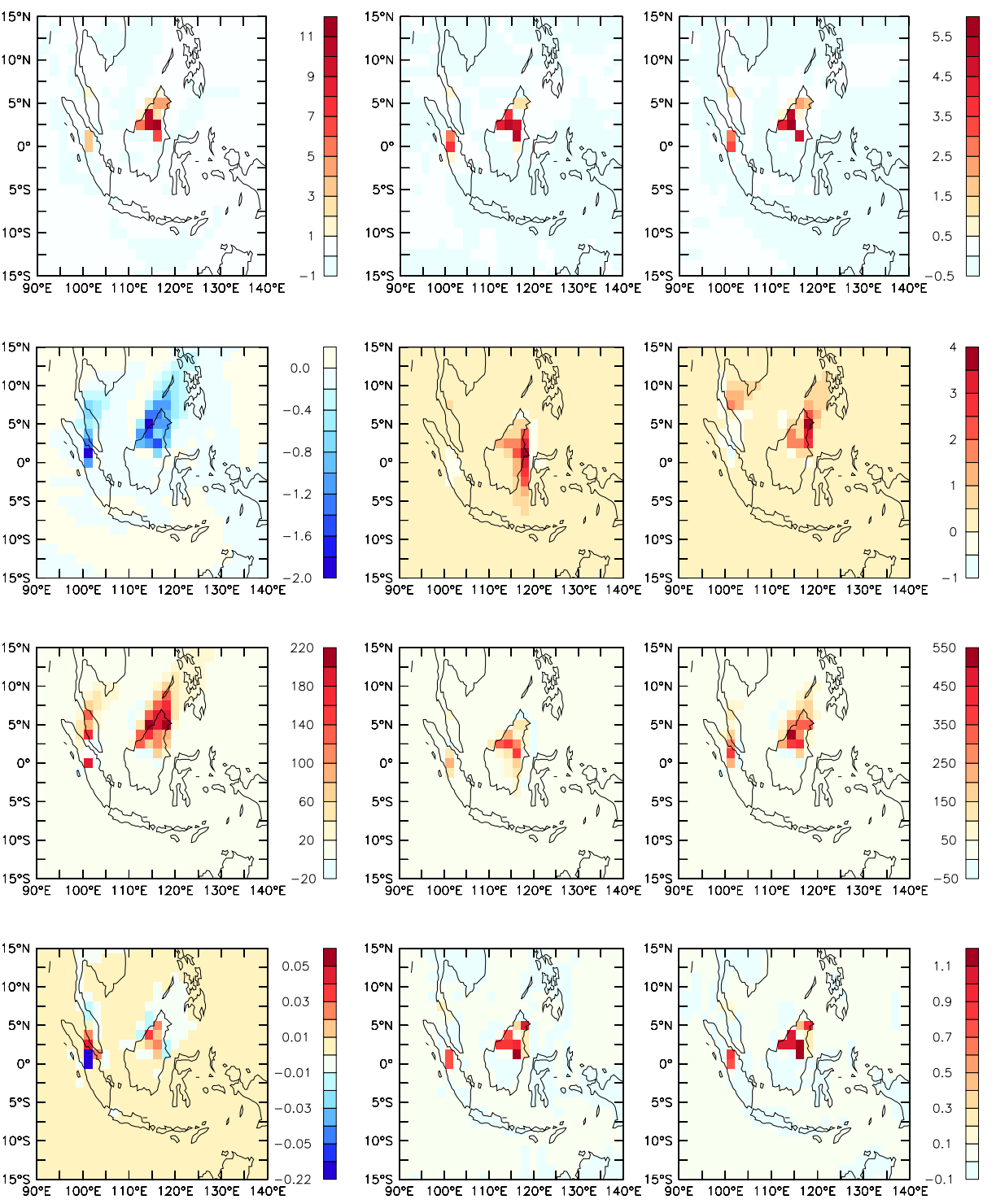

Fig. 1. Differences in monthly mean surface concentrations over SE Asia for PALM vs. CTRL (first two columns) and PALM_NO ${ }_{x}$ vs. CTRL (last two columns). The first column for each scenario shows monthly mean differences for January and the second shows July. The first row shows differences in isoprene, the second ozone, the third bSOA and the final row $\mathrm{NO}_{\mathrm{x}}$. Note the scales for PALM and PALM_NO $\mathrm{X}_{\mathrm{x}}$ differ.

In the PALM scenario, ozone decreases markedly (with monthly mean reductions of as much as $2.7 \mathrm{ppbv}$ or $8 \%$ from CTRL) in the immediate vicinity of the new plantations in response to the increased emissions. The increase in reactive carbon released into the atmosphere leads to small increases in surface ozone concentration further downwind of the plantations, leading to a negligible overall impact on ozone concentrations across the region (annual mean reduction of $67 \mathrm{pptv})$.
In contrast, in the PALM_NO ${ }_{x}$ scenario, the additional $\mathrm{NO}_{\mathrm{x}}$ emissions in this region result in a strong increase in ozone production in response to the increase in isoprene. $\mathrm{Al}-$ though the annual average surface ozone concentration increases by only $0.2 \mathrm{ppbv}$ across the region as a whole, increases of greater than $2 \mathrm{ppbv}$ (around 10\%) are seen over large parts of Borneo. Some locations experience changes in monthly mean ozone concentrations of over $+6.5 \mathrm{ppbv}$ (an increase of over $25 \%$ ). While ground-level ozone increases strongly over the new oil palm sites, slight reductions are 
evident upwind of the new plantations in both January and July (see Fig. 1) with more substantial decreases in monthly means (of up to $1 \mathrm{ppbv}$ or $2.5 \%$ ) in the vicinity of Singapore and Kuala Lumpur in July as the increased isoprene emissions result in a strong increase in the VOC: $\mathrm{NO}_{\mathrm{x}}$ ratio in spite of the additional $\mathrm{NO}_{\mathrm{x}}$, leading to net ozone destruction.

Enhanced bSOA formation also occurs in the vicinity of the new plantations under both oil palm scenarios, although some areas upwind of the new extensive plantations in Sumatra and Borneo show small decreases, likely due to the different lifetimes of isoprene and atmospheric oxidants (see Table 2 and Fig. 1). On average bSOA concentrations across the region rise only slightly (annual mean concentrations rise by $\sim 1.5 \%$ ), but some locations experience monthly mean

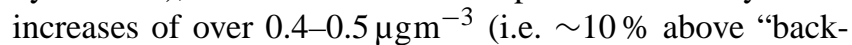
ground" levels). In both scenarios, the spatial distribution of bSOA changes is similar to the ozone response (although of opposite sign in the case of the PALM scenario), as both are affected by the increase in VOC concentration.

In PALM, $\mathrm{NO}_{\mathrm{x}}$ mixing ratios generally decrease due to increases in the formation of nitrates, although increases are seen over the new oil palm plantations in more pristine areas due to enhanced removal of the $\mathrm{OH}$ radical by isoprene, resulting in lower production of nitric acid. A similar response is seen in PALM_NO ${ }_{\mathrm{x}}$, although $\mathrm{NO}_{\mathrm{x}}$ levels increase more strongly over the new plantations and processing plants. The addition of $\mathrm{NO}_{\mathrm{x}}$ into this region also damps the seasonality in the response of the longer-lived atmospheric pollutants, such as $\mathrm{CO}$ and PAN, as the $\mathrm{NO}_{\mathrm{x}}$ concentrations in air masses entering the region becomes less critical.

\subsection{S America}

The Amazon region of S America is a remote (low-NOx) environment with very high isoprene emissions (see e.g. Lelieveld et al., 2008). The atmospheric response here is governed by the availability of $\mathrm{NO}_{\mathrm{x}}$, which is strongly influenced by biomass burning. During the main burning season (August-October, see e.g. Stavrakou et al., 2009) $\mathrm{NO}_{\mathrm{x}}$ concentrations in the lower troposphere in this region are nearly twice the annual average in CTRL. "Background" (annual mean averaged across the region) levels of ozone are lower

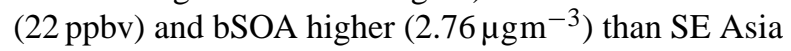

The response of the region to increased isoprene emissions (up $5 \%$ from 162 to $165 \mathrm{Tgy}^{-1}$ ) is qualitatively similar to that seen in SE Asia. Table 2 provides a summary of the changes in ozone and bSOA for both regions for comparison. Changes in annual mean concentrations are shown in Fig. 2. In general, surface ozone concentrations decrease under PALM, and increase when co-located $\mathrm{NO}_{\mathrm{x}}$ emissions are included in PALM_NO ${ }_{x}$; bSOA concentrations increase under both oil palm scenarios. Again the seasonality of the changes is damped by the additional $\mathrm{NO}_{\mathrm{x}}$ in PALM_NO${ }_{\mathrm{x}}$, but in this region it is biomass burning driving the seasonality seen in PALM.
Changes in both bSOA and ozone mean concentrations (annual and monthly) are negligible if averaged across the region as a whole. Relative changes in the vicinity of the new oil palm plantations are again substantial for both scenarios, with increases of $\sim 10 \%$ in annual mean ozone and bSOA concentrations. Under the PALM scenario, the maximum response occurs in August when $\mathrm{NO}_{\mathrm{x}}$ concentrations peak due to biomass burning in the region, with a decrease of nearly 4 ppbv $(\sim 10 \%)$ in surface ozone concentration and increase of $0.6 \mu \mathrm{gm}^{-3}(\sim 11 \%)$ in bSOA concentration. The additional $\mathrm{NO}_{\mathrm{x}}$ concentrations in PALM $\mathrm{NO}_{\mathrm{x}}$ result in stronger responses outside of the period of biomass burning with a maximum increase in surface ozone of $\sim 2.5$ ppbv (nearly $30 \%$ ) in March when "background" $\mathrm{NO}_{\mathrm{x}}$ levels across the region are low.

\subsection{Africa}

The atmospheric impacts of increasing isoprene emissions (up $1 \%$ from 58 to $59 \mathrm{Tgy}^{-1}$ ) show a strong contrast between the polluted and remote areas in this region. The background $\mathrm{NO}_{\mathrm{x}}$ concentrations differ considerably between the two areas of greatest land use change: Central Africa (monthly mean surface concentrations of $0.8-2.8 \mathrm{ppbv}$ ) and Niger Delta (1.3-4.5 ppbv), affecting the magnitude and direction of the changes in ozone concentrations. A summary of the changes in ozone and bSOA concentrations across the region as a whole as well as Central Africa and the Niger Delta is given in Table 2. Figure 3 shows the spatial distribution of the changes in annual mean concentrations under the two oil palm scenarios.

Changes in both bSOA and ozone mean concentrations (annual and monthly) are again negligible if averaged across the region as a whole, but more substantial in areas local to the change in land cover. SOA increases under both scenarios, with annual mean changes roughly proportional to the increase in isoprene emissions in each region.

Over the " $\mathrm{NO}_{\mathrm{x}}$-sensitive" area of Central Africa, ozone concentrations fall substantially as isoprene emissions increase, with decreases of over $1.6 \mathrm{ppbv}(6 \%)$ in annual mean and $2.8 \mathrm{ppbv}(6 \%)$ in January monthly mean under PALM. The addition of $\mathrm{NO}_{\mathrm{x}}$ emissions due to oil palm processing in the PALM $\_\mathrm{NO}_{\mathrm{x}}$ scenario reduces the impact, but surface ozone still falls by as much as 1 ppbv (nearly $4 \%$ ) in January. By contrast, the more polluted area of the Niger Delta experiences slight increases in annual and monthly mean ozone concentrations (around $1 \%$ ) under PALM_NO ${ }_{\mathrm{X}}$, and positive but negligible changes under PALM. 

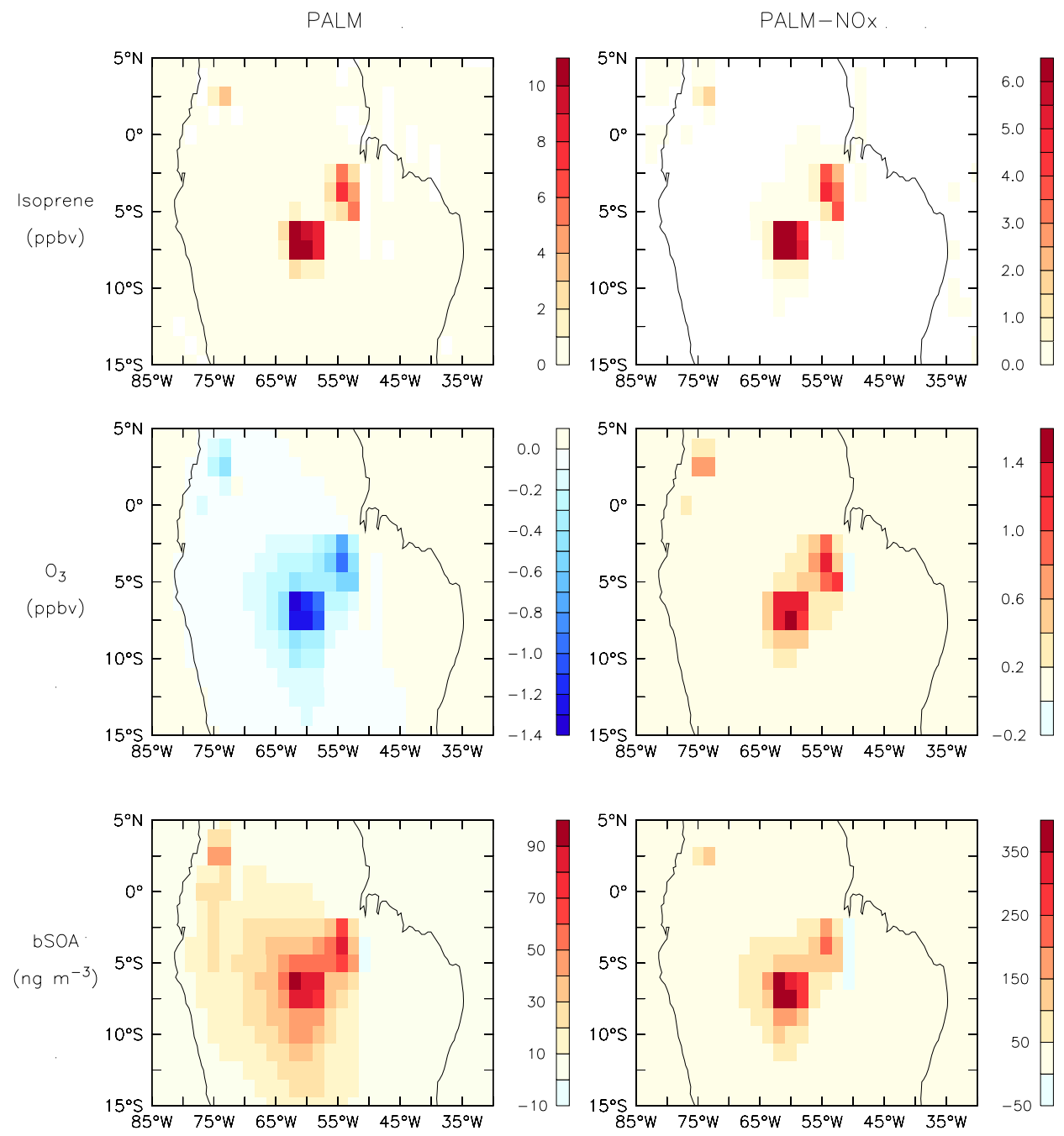

Fig. 2. Differences in annual mean surface concentrations of isoprene (top), ozone (middle) and SOA (bottom) for Amazonia for PALM vs. CTRL (left) and PALM_NO ${ }_{\mathrm{x}}$ (right). Note change of scale from PALM to PALM_NO ${ }_{\mathrm{x}}$.

\section{Results from the SRC scenario}

Replacing 92 Mha of current agricultural crops with SRC increases total global isoprene emissions by just under $1 \%$, roughly the same as in PALM. Table 3 shows the changes in ground-level concentrations of ozone and bSOA. Again, the change in tropospheric $\mathrm{OH}$ is insufficient to appreciably affect methane lifetime. Changes in atmospheric mixing ratios are generally smaller in magnitude but greater in spatial extent than the oil palm scenarios, in line with the different planting density.

\subsection{Europe}

Planting of SRC occurs throughout this region, though the planting density varies according to identified land availability. In the HadGEM2 model, Europe is characterised by high background levels of both $\mathrm{NO}_{\mathrm{x}}$ and ozone, with sim- ulated annual averages of about $4.6 \mathrm{ppbv}$ and $40 \mathrm{ppbv}$ respectively. Ozone concentrations peak in the south of the region (at around $25 \mathrm{ppbv}$ in January and $50 \mathrm{ppbv}$ in July), and $\mathrm{NO}_{\mathrm{x}}$ in the north-west. The topography of the region plays an important role in air quality, particularly around the Mediterranean basin, and extensive transport of atmospheric pollution away from Europe occurs in all directions (Duncan and Bey, 2004).

Annual isoprene emissions increase by $16 \%$ (from 23 to $26 \mathrm{Tgy}^{-1}$ ) across the region, with the spatial distribution of the changes reflecting the magnitude of the land use change. Table 3 summarises the effect of this increase on surface ozone and bSOA concentrations in Europe, and Figure 4 shows the distribution of the monthly mean changes in January and July. While changes in the annual mean concentrations are slight (just under $1 \%$ for ozone and $\sim 3 \%$ for aerosol), summertime increases are more substantial. 

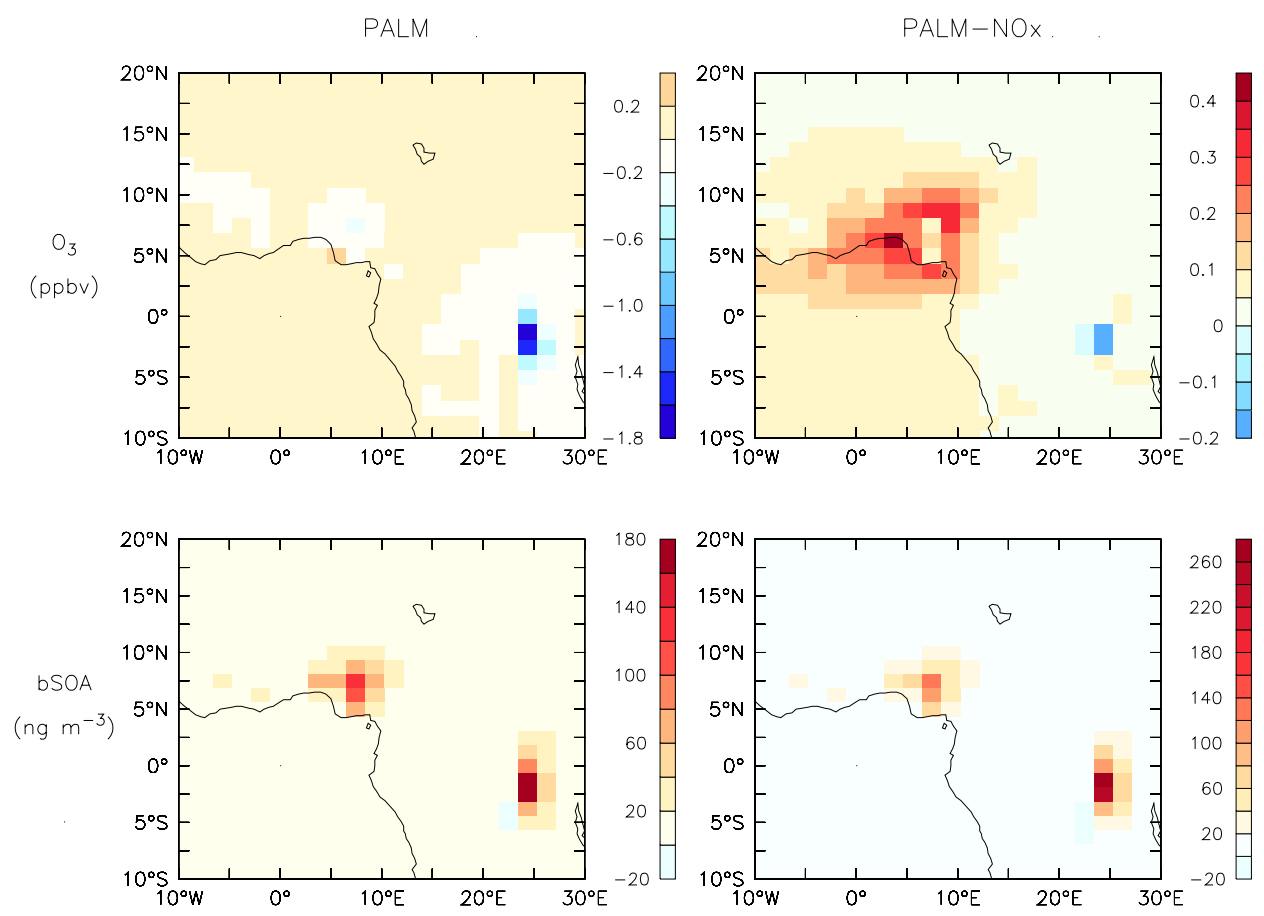

Fig. 3. Differences in annual mean surface concentratmbo emissionsions of ozone (top) and SOA (bottom) for Africa for PALM vs. CTRL. (left) and PALM_NO ${ }_{x}$ vs. CTRL (right). Note change of scale from PALM to PALM_NO ${ }_{\mathrm{X}}$.

Monthly mean surface ozone increases by just over $0.6 \mathrm{ppbv}$ in July, with parts of Eastern Europe experiencing increases of over 2 ppbv (nearly $3 \%$ ) The monthly mean concentration of bSOA across the region increases by $\sim 0.1 \mu \mathrm{gm}^{-3}$ (nearly $5 \%$ ) in June and July. The impact is greatest over southeastern Europe with increases of over $0.5 \mu \mathrm{gm}^{-3}(\sim 8 \%)$ in monthly mean concentrations in the summer.

Isoprene emissions and atmospheric concentrations of isoprene, ozone and bSOA in Europe follow a strongly seasonal pattern, with peak monthly increases of up to 3 times the annual mean. Surface concentrations of ozone and bSOA increase throughout much of the region with maximum elevation in south-eastern and central Europe. The region between the Adriatic and Black Sea exhibits a decrease in ozone in response to increasing isoprene emissions as it is a " $\mathrm{NO}_{\mathrm{x}}$ sensitive region" as described in Sect. 2.3. There is also evidence of transport south across the Mediterranean, extending well into North Africa, particularly in July, when biogenic emissions peak. $\mathrm{NO}_{\mathrm{x}}$ mixing ratios fall across Europe due to increased formation of PAN and organic nitrates with the largest changes in central Europe.

\subsection{N America}

Under the SRC scenario, considerably less land is converted to biofuel cultivation in N America than Europe (18 Mha vs. $70 \mathrm{Mha}$ ). Changes in isoprene emissions (up $2 \%$ from 34 to $35 \mathrm{Tgy}^{-1}$ ) and the subsequent impact on atmospheric com-
Table 3. Summary of changes in ground-level ozone and biogenic SOA concentrations for the SRC scenario

\begin{tabular}{|c|c|c|}
\hline & $\begin{array}{c}\text { Ozone (ppbv) } \\
\text { SRC }\end{array}$ & $\begin{array}{c}\mathrm{bSOA}\left(\mu \mathrm{gm}^{-3}\right) \\
\mathrm{SRC}\end{array}$ \\
\hline $\begin{array}{l}\text { Global: } \\
\text { Annual mean }\end{array}$ & $+0.05[<1 \%]$ & $<+0.01[<1 \%]$ \\
\hline $\begin{array}{l}\text { Europe }^{\mathrm{a}} \text { : } \\
\text { Annual mean } \\
\text { Max monthly mean }^{\mathrm{b}} \\
\text { Peak annual mean } \\
\text { Peak monthly mean }^{\mathrm{c}}\end{array}$ & $\begin{array}{c}+0.32[<1 \%] \\
+0.64[1 \%] \\
+0.89[3 \%] \\
+2.26[3 \%]\end{array}$ & $\begin{array}{l}+0.04[3 \%] \\
+0.11[5 \%] \\
+0.22[6 \%] \\
+0.56[8 \%]\end{array}$ \\
\hline $\begin{array}{l}\text { N America }{ }^{\mathrm{d}}: \\
\text { Annual mean } \\
\text { Max monthly mean }^{\mathrm{b}} \\
\text { Peak annual mean } \\
\text { Peak monthly mean }^{\mathrm{c}}\end{array}$ & $\begin{array}{c}+0.07[<1 \%] \\
+0.13[<1 \%] \\
+0.25[<1 \%] \\
+0.53[1 \%]\end{array}$ & $\begin{array}{c}<+0.01[<1 \%] \\
+0.02[<1 \%] \\
+0.03[2 \%] \\
+0.08[2 \%]\end{array}$ \\
\hline
\end{tabular}

${ }^{\text {a }}$ Europe domain taken as $12.2^{\circ} \mathrm{W}, 35.6^{\circ} \mathrm{N}$ to $45.9^{\circ} \mathrm{E}, 60.6^{\circ} \mathrm{N}$.

$\mathrm{b}$ Values given are the area weighted average change calculated across the stated domain.

${ }^{c}$ Values given are the maximum change in any individual gridbox in the stated domain.

${ }^{\mathrm{d}} \mathrm{N}$ America domain taken as $124.7^{\circ} \mathrm{W}, 29.4^{\circ} \mathrm{N}$ to $74.1^{\circ} \mathrm{W}, 53.1^{\circ} \mathrm{N}$.

The domains were selected to give roughly the same total area.

position are therefore also substantially lower. As shown in Table 3, increases in surface ozone and bSOA concentrations are negligible across most spatial and temporal ranges. 

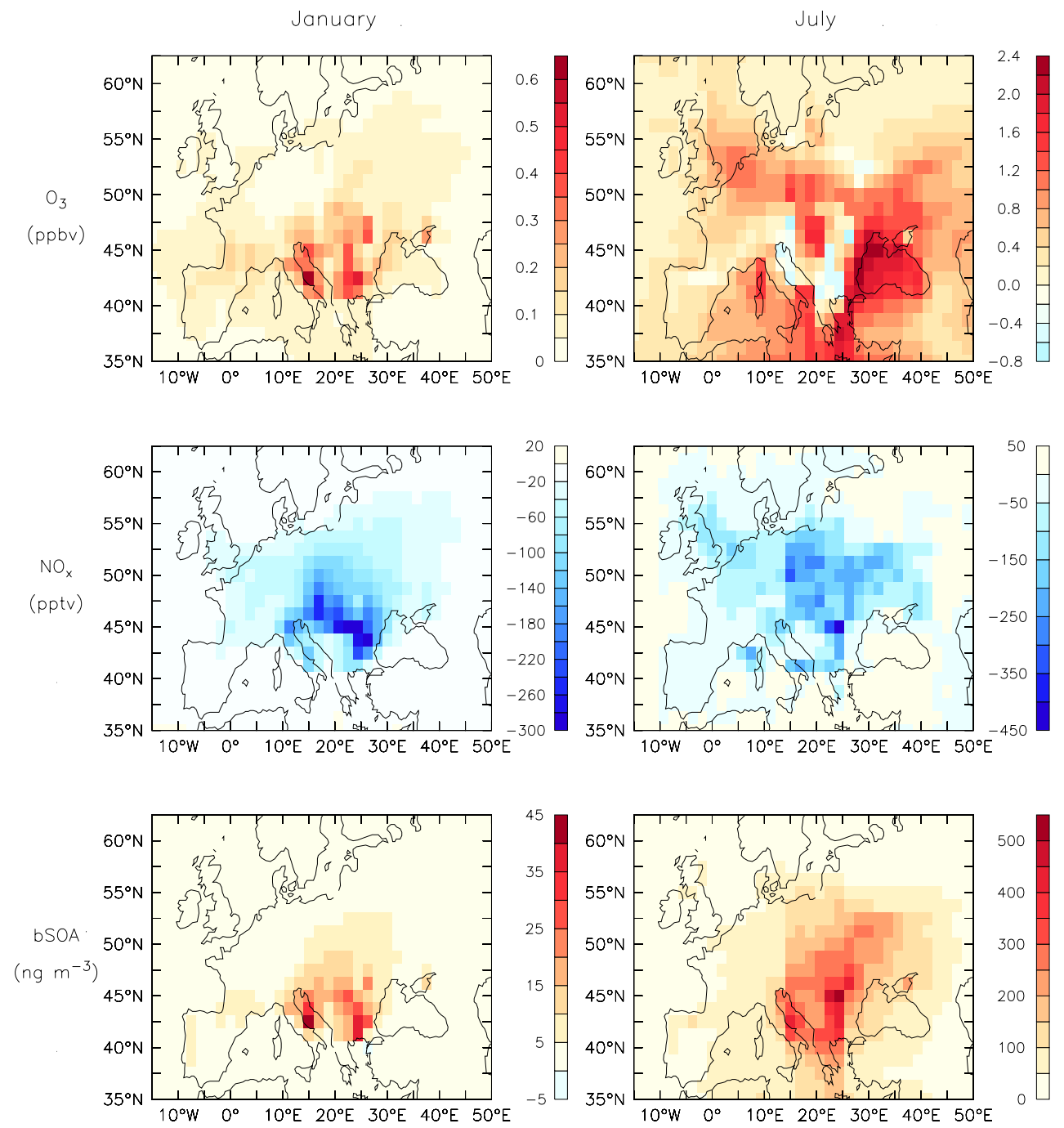

Fig. 4. Differences in monthly mean surface concentrations of ozone (top), $\mathrm{NO}_{\mathrm{x}}$ (middle) and SOA (bottom) for Europe in January (left) and July (right) for SRC vs. CTRL. Note change of scale from January to July.

Figure 5 shows the spatial distribution of changes in annual mean ozone (top) and bSOA (bottom) concentrations across $\mathrm{N}$ America as a result of biofuel cultivation in the Pacific NW, mid-west and SE USA. While the magnitude of the response is highly seasonal, the spatial distribution of the changes is consistent through the year. It is noteworthy that surface ozone concentrations fall in two of the regions of cultivation: SE USA and Pacific NW. In both regions, biogenic emissions are high (see e.g. Guenther et al., 2006), making them " $\mathrm{NO}_{\mathrm{x}}$-sensitive". Hence, an increase in VOC emissions and atmospheric concentrations increase the VOC: $\mathrm{NO}_{\mathrm{x}}$ ratio further, moving these regions away from the optimum ratio for ozone production (Sillman, 1999). The maximum decrease in monthly mean surface ozone in each of these regions is $-0.3 \mathrm{ppbv}$ (a decrease of $0.6 \%$ in both cases).

Only 4 Mha of SRC is planted in Australia, resulting in a $1 \%$ increase in isoprene emissions (from 1.9 to $2.0 \mathrm{Tgy}^{-1}$ ).
Changes in surface ozone and bSOA concentrations are negligible on all temporal and spatial scales.

\section{Sensitivity to deposition}

Our model simulations with HadGEM2 suggest changes in isoprene emissions due to biofuel cultivation will affect atmospheric composition on a local to regional scale. However, changes in land surface directly affect the deposition of gases and particles (e.g. Wesely, 1989; Ganzeveld and Lelieveld, 2004). In particular, Ganzeveld et al. (2010) demonstrated that changes in ozone dry deposition velocities effectively negated the simulated changes in ozone formation rates resulting from altered isoprene emissions due to LUC.

To assess the effect of changes in dry deposition on ground-level ozone concentrations, we performed 

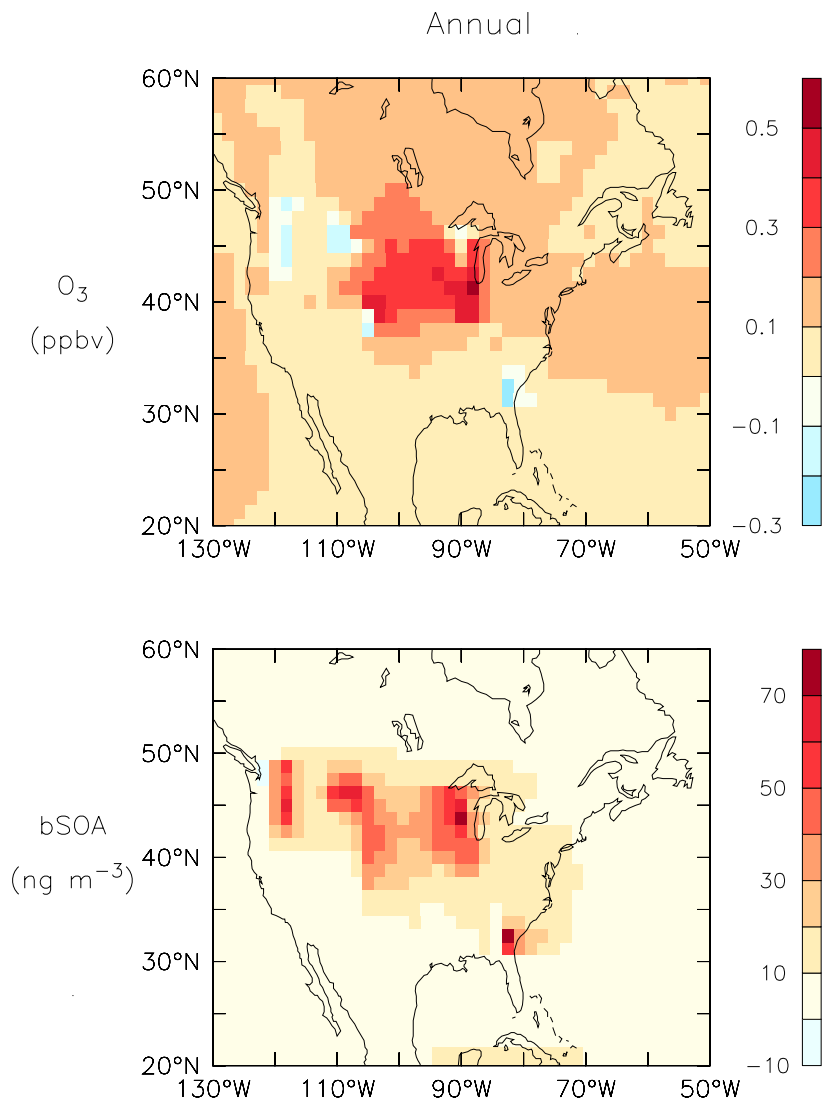

Fig. 5. Differences in annual mean surface concentrations of ozone (top) and SOA (bottom) for N America for SRC vs. CTRL.

short sensitivity studies using the FRSGC/UCI chemistrytransport model (CTM) (Wild et al., 2003). These experiments used the same planting changes as in our HadGEM2 studies, but allowed us to explore the effects of changes in vegetation and surface characteristics (e.g. leaf area and roughness length) in greater detail. Appendix B describes how the roughness length and leaf area values were changed in the CTM as a result of the LUC in the oil palm and SRC scenarios. Dry deposition is modelled in the CTM following the Wesely (1989) deposition scheme.

In general, the CTM showed the same spatial response to the changes in isoprene emissions as HadGEM2, although the magnitude of the increases in ozone under the PALM $\_\mathrm{NO}_{\mathrm{x}}$ and SRC scenarios was slightly greater. The top row of Fig. 6 shows the changes in annual mean surface ozone concentrations over SE Asia and Europe simulated by the CTM without changes to dry deposition. Changes in surface ozone concentrations for the two scenarios with altered dry deposition is shown in the bottom row of Fig. 6.

Replacing tropical rainforest with oil palm plantations reduces the loss of ozone and oxidised nitrates through dry deposition as both leaf area and roughness length are reduced in the replanted areas. Averaged across a grid cell, leaf area typ- ically decreases by $\lesssim 5 \%$ and roughness length by $\sim 5-10 \%$. The increases in ozone simulated by the FRSGC/UCI CTM for the PALM $\mathrm{NO}_{\mathrm{x}}$ scenario are around 7-9\% higher when deposition is allowed to change than the increases projected in simulations in which deposition does not alter. This suggests that the changes in air quality simulated by HadGEM 2 are conservative.

The response to the inclusion of deposition changes in the SRC scenario in the CTM is smaller in magnitude than PALM. During the growing season, deposition is slightly reduced, leading to additional increases in ground-level ozone of around 2-3\% (50-60 pptv) across Europe. Again these findings suggest that during the times of year that air quality is an issue in the Northern mid-latitudes the increases seen in the HadGEM2 simulations are smaller than they would be if vegetation impacts on deposition were also taken into account.

\section{Discussion}

\subsection{Other bVOCs}

Changes in vegetation will lead to changes in the emissions of VOCs other than isoprene, many of which can also be expected to affect atmospheric composition and air quality through changes to the rate of production and loss of ozone and secondary organic aerosols. Of particular interest in the context of the LUC scenarios developed for this study are monoterpenes and methanol emissions.

Monoterpenes are highly reactive, with an atmospheric lifetime of minutes to hours (Atkinson and Arey, 2003), and have long been identified as major sources of secondary organic aerosols (e.g. Went, 1960; Lee et al., 2006). Changes in monoterpene emission rates would therefore be expected to have a demonstrable effect on bSOA concentrations, but only a small effect on surface ozone concentrations, as total global monoterpene emissions are small compared to those of isoprene (e.g. Guenther et al., 1995; Arneth et al., 2007). Measurement data from the OP3 field campaigns (Hewitt et al., 2010) show that monoterpene fluxes accounted for nearly $20 \%$ of bVOC emissions from tropical rainforest (Langford et al., 2010) but were negligible from oil palm (Misztal et al., 2011). Hence, monoterpene emissions would be substantially lower under the oil palm scenarios, possibly negating the increase in bSOA concentrations simulated due to the strong increase in isoprene emissions. Changes in monoterpene emission rates for the SRC scenario are harder to quantify. Both total emission rate and precise compound mix vary widely between species (e.g. Sakulyanontvittaya et al., 2008). Flux measurements presented by Sakulyanontvittaya et al. (2008) suggest that total monoterpene emissions from broadleaf trees are slightly higher than from crops and grasses (although the variability in the measurements is high). Data collated by Simpson et al. (1995) shows that 

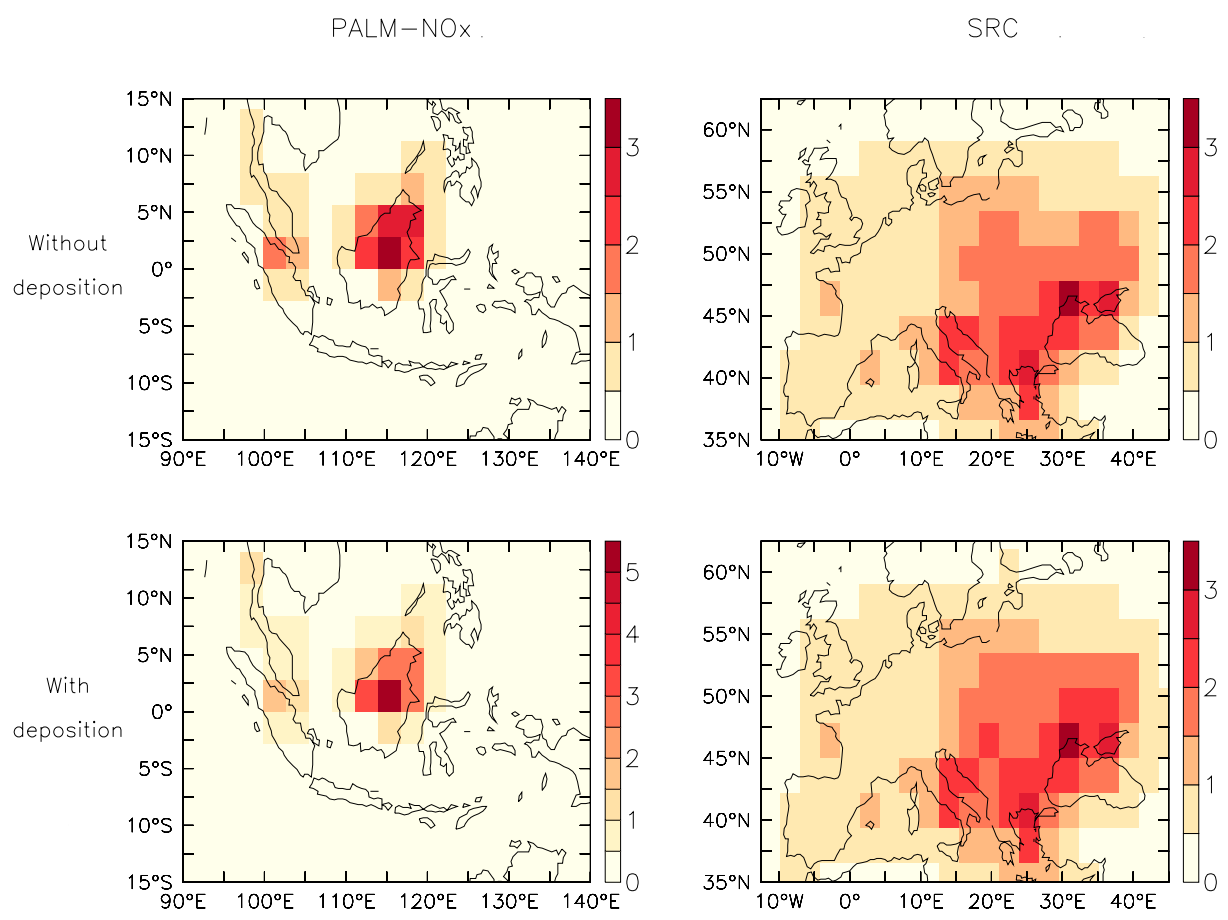

Fig. 6. Differences in annual mean surface ozone concentrations for PALM_NO ${ }_{x}$ vs. CTRL. (left) and SRC vs. CTRL (right) without changes in dry deposition (top) and with changes in dry deposition (bottom).

while broadleaf trees emit more monoterpenes than grasses, crops are slightly higher emitters. Emission factors used by Guenther et al. (1995) result in much higher emissions from broadleaf trees than either crops or grasses, particularly for re-growing woodland. Overall, these studies would suggest that monoterpene emissions would be little affected by replacing crops and grasses with broadleaf trees (although Simpson et al. (1995) suggests that of the broadleaf species used in the SRC scenario (poplar, willow and eucalyptus) only eucalyptus has been observed to emit monoterpenes).

The terrestrial biosphere is a major source of methanol which has a well-documented influence on tropospheric ozone (e.g. Tie et al., 2003, and references therein). Measurements of methanol fluxes from rainforest and oil palm (Langford et al., 2010; Misztal et al., 2011) show that emission rates from the two canopies are very similar, and that both ecosystems are net sinks rather than sources. Hence, we would expect changes in both methanol emissions and subsequent ozone formation to be negligible in the oil palm scenarios considered here. Again, quantification of the effect of the SRC scenario on methanol emissions is hard. Stavrakou et al. (2011) assumes emission factors of $400 \mu \mathrm{gm}^{-2} \mathrm{~h}^{-1}$ for crops and grasses, $800 \mu \mathrm{gm}^{-2} \mathrm{~h}^{-1}$ for Northern temperate broadleaf trees and $400 \mu \mathrm{gm}^{-2} \mathrm{~h}^{-1}$ for broadleaf trees elsewhere. However, the authors also note that emissions have been observed to be very speciesdependent with a factor of 3 variation in fluxes measured from different grasses, and, more importantly, that methanol emissions are more strongly affected by leaf age than any other factor. As SRCs, which are harvested by cutting to ground-level every $2-3$ years, replace a mixture of annual crops and perennial grasses, the leaf age effects may balance. Methanol emission rates would therefore be expected to rise, due to the differences in emission factors, across the SRC plantations in the Northern mid-latitudes, enhancing the change in ozone in these regions. It should of course be noted that the effect of bVOC emissions is highly non-linear and there are likely to be areas where increasing isoprene and methanol emissions leads to a decrease in net formation of ozone.

Other bVOCs have also been observed to be emitted in large quantities from certain ecosystems, particularly 2methyl-3-buten-2-ol (e.g. Steiner et al., 2007), sesquiterpenes (e.g. Sakulyanontvittaya et al., 2008; Jardine et al., 2011), oxygenated VOCs (e.g. Ruuskanen et al., 2011) and estragole from oil palm (Misztal et al., 2010). Many of these are known to affect atmospheric composition, playing a role in governing the formation of bSOA (e.g. Sakulyanontvittaya et al., 2008; Lee et al., 2006) and the rate of production or loss of tropospheric ozone (Steiner et al., 2007; Jardine et al., 2011) that may be significant on a local scale. Emissions of sesquiterpenes, oxygenated VOCs and estragole are all likely to be affected by the biofuel cultivation scenarios considered in this study.

While a robust simulation of the emissions and atmospheric reactions of these compounds is not possible at 
present, due to the large uncertainties involved, it is a question that should be addressed in the near future.

\subsection{Other impacts of LUC}

Direct climate impacts from land use change result from biogeophysical and biogeochemical changes in surface energy and mass fluxes through changes in, for exapmle, surface albedo or the hydrological cycle (e.g. Bathiany et al., 2010; Davin et al., 2007, and references therein). In the two oil palm scenarios, the impacts of replacing native forest with oil palm, another broadleaf tree species, are likely to be small on both the global and regional scale. While the introduction of heterogeneity into the landscape may give rise to localised edge effects (as reported over West Africa by Garcia-Carreras et al. (2010)), the limited magnitude and extent of the replanting are not expected to substantially affect large-scale atmospheric circulation or surface temperature. Previous modelling studies of deforestation in SE Asia have shown a wide spread of model-dependent temperature responses. The most recent, and most comprehensive, studies of this region (e.g. Schneck and Mosbrugger, 2011; Delire et al., 2001) show increases of between 0.7 and $1.25^{\circ} \mathrm{C}$ over Borneo and Sumatra (although decreases over other parts of the region) as a result of complete deforestation. Temperature increases in response to our planting, while expected to be smaller, would further increase isoprene emissions (e.g. Guenther et al., 1995; Arneth et al., 2007) in the region, making our simulated air quality changes a conservative estimate.

In the mid-latitudes, reforestation is likely to result in higher regional temperatures as surface albedo decreases (e.g. Betts et al., 2007). The small scale of the changes in vegetation would be expected to limit this effect. In addition, the growing conditions, heights and seasons of SRC are similar to that of the agricultural crops that they are replacing, reducing the direct climate impacts of such LUC. This again suggests that our projected ozone increases are lower than they would be with inclusion of climate responses.

\subsection{Comparison with previous work}

While our results are consistent with the findings of previous studies, our much smaller changes in isoprene emissions, resulting from more realistic levels of biofuel cultivation, lead to correspondingly smaller impacts on atmospheric composition and air quality.

In contrast with most previous studies of the impact of LUC on bVOC emissions and atmospheric composition, our scenarios result in increased isoprene emissions. Our realistic, small-scale biofuel cultivation scenarios, based on current policy projections for 2020 , represent considerably smaller changes in land cover than the previous studies outlined in Sect. 1, which tended to implement "worst-case" LUC scenarios. However, our results are qualitatively simi- lar to earlier work although the magnitude of the impacts is substantially reduced.

Wiedinmyer et al. (2006) found that the atmospheric effects of biofuel cultivation in the Amazon and western US were limited to these regions. Furthermore, in both the Amazon and Pacific NW, surface ozone concentrations fell, by up to $7 \mathrm{ppbv}$ in July, in response to the $37 \%$ total increase in isoprene emissions. While the direction of the change is the same in our study (see Figs. 2 and 5), we find decreases of only $0.2 \mathrm{ppbv}$ in July monthly means, although the peak reduction in monthly mean surface ozone in the Amazon is over $3.5 \mathrm{ppbv}$ (in August).

Pyle et al. (2011) performed a sensitivity study, replacing isoprene emissions from all native rainforest on the island of Borneo (a total of $\sim 72 \mathrm{Mha}$, compared with $\sim 21$ Mha here) with oil palm emissions. When additional $\mathrm{NO}_{\mathrm{x}}$ emissions from oil palm processing were included, their model simulation (for May) projected ozone increases of up to $15 \mathrm{ppbv}$ (compared to monthly mean changes of just over 4 ppbv for May here) over the island with appreciable enhancement also seen downwind.

Ganzeveld et al. (2010) calculated that under the IPCC SRES A2 scenario (Nakicenovic and Swart, 2000) for LUC, isoprene emissions were reduced through much of the tropics due to deforestation and slightly increased in Europe and SE USA. Our study, in contrast, shows that LUC for biofuel cultivation results in increases in isoprene emissions everywhere. The authors also found that reductions in leaf area resulted in lower ozone dry deposition velocities in all areas apart from eastern Europe where leaf area and deposition increased. We simulate reductions in dry deposition everywhere under both oil palm and SRC cultivation, again driven by reductions in leaf area. In the case of the SRC and PALM_NO ${ }_{x}$ scenarios the decrease in ozone loss through deposition enhances the increase in surface ozone caused by the projected increase in isoprene emissions, although the effect is small (2-3\% of the increase without deposition changes over Europe under SRC and 7-9\% in SE Asia under PALM_NO ${ }_{\mathrm{x}}$ ). However, as discussed by Ganzeveld et al. (2010), the overall impact of future LUC on surface ozone concentrations is sensitive to the relative changes in emissions of VOC and $\mathrm{NO}_{\mathrm{x}}$ (both biogenic and anthropogenic), deposition rates and boundary layer height and dynamics. The response of the system is highly complex, and given our incomplete understanding of the processes involved, model dependent.

In line with the results of Chen et al. (2009) and Heald et al. (2008), we find that bSOA concentrations change roughly in proportion to the change in total bVOC emissions, although both previous studies reported a decrease in bSOA in response to a decrease in bVOC emissions, with the magnitude of the response more strongly related to monoterpene, rather than isoprene, emission changes. 


\subsection{Uncertainties}

There are substantial uncertainties involved in the model simulations described in this work, arising from a lack of fundamental understanding of the processes involved, the simplifications required to include complex processes in global models, the coarse resolution used and in the development of future scenarios.

Guenther et al. (1995) suggested an uncertainty of a factor of 3 in their estimate of $500 \mathrm{TgCy}^{-1}$ for global isoprene emissions due to modelling simplifications and assumptions (e.g. regarding vegetation distribution and the use of a single emission factor for broad categories of vegetation). Guenther et al. (2006) showed that the use of different input datasets for meteorology or vegetation types and characteristics led to estimates that varied by as much as $-11 \%$ and $+29 \%$ from the "standard" model set-up. By contrast, Arneth et al. (2007) showed that, in spite of widely differing input datasets all global isoprene emissions estimates to date appear to converge on a value of $\sim 500 \mathrm{TgCy}^{-1}$, but noted that the uncertainty is substantially larger than the apparent consensus suggests.

While global emissions estimates agree closely, comparisons of instantaneous modelled emissions against flux measurement data show large differences. For example, Müller et al. (2008) found that modelled hourly fluxes at a site in the Northern mid-latitudes were, on average, $35 \%$ lower than measured fluxes, while emissions estimated in the Amazon were between a factor of 2 and 5 times too high in the wet season. Langford et al. (2010) reported that emissions estimated with the MEGAN algorithms (Guenther et al., 2006) over SE Asian rainforest were 4 times higher than observed fluxes.

By necessity, the gas-phase atmospheric reactions of VOCs including isoprene are greatly simplified in atmospheric chemistry models (e.g. Pöschl et al., 2000). By virtue of the number of reactions and compounds that affect the rate of chemical production and loss of tropospheric ozone, ozone is well buffered in these models (Wild, 2007). As a result, model intercomparisons generally show good agreement between chemical mechanisms (simulated concentrations generally agree to within $25 \%$ ) in moderate to high $\mathrm{NO}_{\mathrm{x}}$ conditions (Archibald et al., 2010; Pöschl et al., 2000; von Kuhlmann et al., 2004). Model divergence is greater in low- $\mathrm{NO}_{\mathrm{x}}$ environments (Archibald et al., 2010; Pöschl et al., 2000) with differences in ozone concentrations of as much as a factor of 2. This can be accounted for, in part, by the different treatment of organic nitrates (e.g. isoprene nitrate and peroxyacetylnitrate or PAN), in particular their rate of formation and yield, and the rate and efficiency of reactive nitrogen recycling by these species (see e.g. Ito et al., 2009; von Kuhlmann et al., 2004). In addition, it has been shown recently that, in low- $\mathrm{NO}_{\mathrm{x}}$ environments with high isoprene emissions, concentrations of the $\mathrm{OH}$ radical are far higher than would be expected from our current understanding of isoprene chemistry (Lelieveld et al., 2008; Pugh et al., 2010). While various alternative reaction mechanisms have been proposed, none has been validated in the field, and Archibald et al. (2011) has shown that the effect on modelled ozone concentration is very small ( $<5 \%$ for any of the mechanisms).

Comparisons between modelled and measured atmospheric concentrations of ozone generally show good agreement (see e.g. Wild, 2007; Fiore et al., 2009). However, such agreement does not necessarily suggest we should have confidence in model results (Wild, 2007). As discussed by Ganzeveld and Lelieveld (2004) and von Kuhlmann et al. (2004) there are many possible sources of error in modelling atmospheric chemical processes, including bVOC emission estimates, atmospheric reaction mechanisms, deposition velocities, atmospheric dynamics and boundary layer height.

The formation of bSOA is particularly poorly understood, and the processes involved are reduced to a two-product approach in many global chemistry models (Hallquist et al., 2009). Furthermore, it is usually assumed that the molar yield of aerosol particles from the condensable product in such an approach is constant for all environments (see e.g. Derwent et al., 2003; Spracklen et al., 2006; Mann et al., 2010). Divergence between modelled burdens of organic aerosols is high and projections poorly constrained (Carslaw et al., 2010). Measurements suggest that, even in polluted areas, organic aerosol is predominantly biogenic in origin (see e.g. Jimenez et al., 2009; Zhang et al., 2007). Global models have consistently been shown both to underestimate bSOA burden (see e.g. Heald et al., 2005), and to fail to capture the spatial distribution of biogenic aerosols (Spracklen et al., 2011).

While our projected changes in bSOA concentrations are in line with those found in previous studies (Chen et al., 2009; Heald et al., 2008), this is likely to be largely due to the assumption of fixed yields of aerosols from isoprene and monoterpenes. Given recent work highlighting the poor agreement between modelled and measured aerosol concentrations (see e.g. Spracklen et al., 2011), we would suggest that further work is needed before robust projections of bSOA concentrations can be made. In addition, without an understanding of the size distribution of the particles formed, their impact on climate and air quality cannot be established (see e.g. Penner et al., 2001).

Although the changes in isoprene emissions and ozone concentrations simulated in our study are well below the magnitude of the uncertainties involved, our results show a systematic increase in isoprene emissions due to the cultivation of oil palm and SRC biofuel feedstock. Our results agree qualitatively with previous modelling studies and the two atmospheric chemistry models used (the UKCA scheme in HadGEM2 and FRSGC/UCI CTM) show good agreement, lending confidence to the direction and distribution of the changes in surface ozone. 


\subsection{Future work}

In addition to the inclusion of the effects outlined in Sects. 5 and 6, further work is required to assess the impact of transportation of the biofuel to market, and the end use of the fuel. The former will alter the spatial distribution of (predominantly) shipping emissions, which in the case of SE Asia will likely alter the atmospheric response to the increase in isoprene emissions by further raising $\mathrm{NO}_{\mathrm{x}}$ levels in the region. The latter will result in a different mix of tail-pipe emissions.

Future studies should consider climate impacts and changing vegetation responses on isoprene emissions and subsequent reactions, on longer timescales (to 2100) using a fully coupled Earth system model. Higher resolution modelling studies, using for example the UK Meterological Office's regional Earth system model (HadGEM3-R), are required to fully assess the impact of these scenarios on a regional scale and to evaluate the impacts on human health and crop productivity of the increases in ozone and SOA projected here.

\section{Conclusions}

Cultivation of sufficient biofuel feedstock crops to replace around $1 \%$ of projected global fossil fuel demand in 2020 increases global isoprene emissions by about $1 \%$, resulting in changes in surface ozone and secondary organic aerosol concentrations. While small at the global scale, regional air quality impacts are important. The expansion of oil palm plantations in the tropics, together with increased $\mathrm{NO}_{\mathrm{x}}$ emissions from associated processing plants, results in annual average ozone increases of around $0.2 \mathrm{ppbv}$ in SE Asia (from a base of $31 \mathrm{ppbv}$ ), with Borneo experiencing annual mean rises of over $3 \mathrm{ppbv}$ (from $32 \mathrm{ppbv}$ ), peaking at over $6.5 \mathrm{ppbv}$ (from $26 \mathrm{ppbv}$ ) in November over a limited area. Biogenic SOA also increases across the region, with an average enhancement of $0.3 \mu \mathrm{gm}^{-3}$ in annual mean concentrations over much of Borneo and Sumatra (from 6 $-10 \mu \mathrm{gm}^{-3}$ ). The use of short rotation coppice in the mid-latitudes results in increases in annual mean surface ozone concentrations of around $0.3 \mathrm{ppbv}$ over Europe (from $43 \mathrm{ppbv}$ ), with a peak increase of over 2 ppbv (from 79 ppbv) in July over a limited area of Central and Eastern Europe. Biogenic SOA formation is enhanced throughout Europe with increases in concentrations of up to $0.5 \mu \mathrm{gm}^{-3}$ over south-eastern Europe in July (from $8 \mu \mathrm{gm}^{-3}$ ).

A consideration of the likely response of the Earth system to other changes associated with land use change (e.g. changes in surface energy fluxes and deposition rates) suggests that these projected responses represent a conservative estimate of the impact of biofuel cultivation on atmospheric composition and air quality. Given the complexity of the interactions in the system, however, future studies are required using a fully coupled Earth system model.
The location of land use change is important. The low $\mathrm{NO}_{\mathrm{x}}$ regions of the tropics respond differently from the higher $\mathrm{NO}_{\mathrm{x}}$ mid-latitudes, with decreases in surface ozone occurring in the vicinity of new oil palm plantations. Even when $\mathrm{NO}_{\mathrm{x}}$ emissions from biofuel processing are included some areas of the tropics still experience a reduction in ozone as ozone destruction outweighs ozone formation. This effect is also seen in a few locations in the mid-latitudes.

The contrasting response of surface ozone to the increased isoprene emissions in the two oil palm scenarios is a reflection solely of the difference in $\mathrm{NO}_{\mathrm{x}}$ regimes. This supports the conclusions reached by Hewitt et al. (2009), that the future management of nitrogen will play an important role in atmospheric composition and air quality in the tropics. If oil palm processing plant $\mathrm{NO}_{\mathrm{x}}$ emissions can be reduced, then an increase in oil palm cultivation could result in a decrease in surface ozone. If, however, background levels of $\mathrm{NO}_{\mathrm{x}}$ rise in the tropics as a result of increasing industrialisation, even such management measures are likely to be insufficient to prevent an increase in ozone in response to an expansion of the oil palm industry.

This work sugggests that consideration should be given to emissions of VOCs and their effects on atmospheric composition and chemistry when decisions are made regarding the cultivation of biofuel feedstock crops. Life cycle assessments that consider only energy requirements, greenhouse gas emissions and carbon payback times are missing an important impact on air quality and health associated with the cultivation of biofuels. Furthermore, in contrast to life cycle assessments that focus on long-term climate impacts, changes in highly reactive short-lived species such as VOCs have local to regional scale impacts and should therefore be considered as part of a local impact assessment for any new plantation.

\section{Appendix A}

\section{Determining isoprene scaling factors}

Isoprene emissions models use an emission factor (or base emission rate), equivalent to the emission rate of isoprene from $1 \mathrm{~g}$ of dry leaf weight under standard conditions of $30^{\circ} \mathrm{C}$ and $1000 \mu \mathrm{molm}^{-2} \mathrm{~s}^{-1}$ of photosynthetically active radiation. This is then scaled up to the whole plant or canopy level. Although emission factors vary between species, and even genotypes, of plants, an average value is typically assigned to each of the limited number of plant functional types (PFTs) or ecosystems included within the land surface scheme of a global model. Table 4 shows the emissions factors for the relevant PFTs in HadGEM2. Each grid cell within HadGEM2 contains a mixture of PFTs, so the overall emission factor used is the weighted average of the emission factors of all PFTs within that grid cell. A scale factor for the 
Table A1. Values used to scale isoprene emission factors

\begin{tabular}{lc}
\hline PFT & $\begin{array}{c}\text { Emission factor } \varepsilon \\
\left(\mathrm{mggdw}^{-1} \mathrm{~h}^{-1}\right)\end{array}$ \\
\hline Current vegetation & \\
Broadleaf tree & 35 \\
C3 grass & 16 \\
C4 grass & 8 \\
\hline Biofuel crops & \\
Oil palm & 50 \\
Mallee & 45 \\
Eucalyptus & 35 \\
Poplar & 45 \\
Willow & 45 \\
\hline
\end{tabular}

isoprene emissions was calculated for each grid cell in which replanting had taken place. This scale factor, $S$, is defined as:

$S=\frac{\varepsilon}{\varepsilon_{0}}$

where $\varepsilon$ is the modified emission factor for a grid cell, ie under the biofuel scenario, and $\varepsilon_{0}$ the original emission factor for that grid cell under CTRL. For each experiment, the isoprene emissions for each grid cell were calculated as if for the natural vegetation and then multiplied by the scale factor, which is unity in all cells unaffected by re-planting. The modified emission factor, $\varepsilon$, was calculated as shown below. The original weighted grid cell emission factor is calculated by HadGEM2 as:

$$
\begin{aligned}
\varepsilon_{0} & =\sum_{i=1}^{5} \varepsilon \times f \\
& =\varepsilon_{b} \times f_{b}+\varepsilon_{C 3} \times f_{C 3}+\varepsilon_{C 4} \times f_{C 4}+\varepsilon_{n} \times f_{n}+\varepsilon_{s} \times f_{s}
\end{aligned}
$$

where $f$ is the fraction of a grid cell taken up by each PFT, and the subscripts $b, C 3, C 4, n$ and $s$ denote the PFTs broadleaf tree, $C 3$ grass, $C 4$ grass, needleaf tree and shrub respectively.

\section{A1 PALM}

To calculate the modified grid cell emission factor for the oil palm scenarios, a fraction of the broadleaf tree PFT in a grid cell in CTRL is removed and replaced with oil palm. The modified emission factor is given by:

$$
\begin{aligned}
\varepsilon & =\sum_{i=1}^{5} \varepsilon \times f-\varepsilon_{b} \times p \times f_{b}+\varepsilon_{b}^{\prime} \times p \times f_{b} \\
& =\varepsilon_{0}+p \times f_{b} \times\left(\varepsilon_{b}^{\prime}-\varepsilon_{b}\right)
\end{aligned}
$$

where $p$ is the percentage of the broadleaf trees PFT that is being converted to oil palm and $\varepsilon_{b}$ is the base emission rate for oil palm, given in Table 4.
Table B1. Values used to scale leaf area index and roughness lengths used in the FRSGC/UCI CTM

\begin{tabular}{lcc}
\hline PFT & $\begin{array}{c}\text { Biomass density } \\
\left(\mathrm{gm}^{-2}\right)\end{array}$ & $\begin{array}{c}\text { Roughness length, } \mathrm{z}_{0} \\
(\mathrm{~m})\end{array}$ \\
\hline Current vegetation & & \\
Tropical broadleaf tree & $2500^{\mathrm{a}}$ & $3.0^{\mathrm{b}}$ \\
Crops & $1000^{\mathrm{c}}$ & $0.1^{\mathrm{b}}$ \\
Grasses & $400^{\mathrm{c}}$ & $0.05^{\mathrm{b}}$ \\
\hline Biofuel crops & & \\
Oil palm & $2000^{\mathrm{a}}$ & $1.0^{\mathrm{d}}$ \\
Mallee & $400^{\mathrm{c}}$ & $0.5^{\mathrm{b}}$ \\
Eucalyptus & $400^{\mathrm{c}}$ & $0.5^{\mathrm{b}}$ \\
Poplar & $320^{\mathrm{c}}$ & $0.5^{\mathrm{b}}$ \\
Willow & $150^{\mathrm{c}}$ & $0.5^{\mathrm{b}}$ \\
\hline
\end{tabular}

a Relative values taken from data from OP3 campaign (Hewitt et al., 2010)

b Values currently used in the FRSGC/UCI CTM

c Values taken from Simpson et al. (1995)

${ }^{d}$ Calculated from relative heights of oil palm and rainforest (Hewitt et al., 2010)

\section{A2 SRC}

To calculate the modified grid cell emission factor for the SRC scenarios, a fraction of the $C 3$ and $C 4$ grass PFTs in a grid cell in CTRL is removed and replaced with the SRC PFT. The modified emission factor is given by:

$$
\begin{aligned}
\varepsilon & =\sum_{i=1}^{5} \varepsilon \times f-\varepsilon_{C 3} \times p_{C 3} \times f_{C 3}+\varepsilon_{C 3}^{\prime} \times p_{C 3} \times f_{C 3} \\
& -\varepsilon_{C 4} \times p_{C 4} \times f_{C 4}+\varepsilon_{C 4}^{\prime} \times p_{C 4} \times f_{C 4} \\
& =\varepsilon_{0}+p_{C 3} \times f_{C 3} \times\left(\varepsilon_{b}^{\prime}-\varepsilon_{C 3}\right)+p_{C 4} \times f_{C 4} \times\left(\varepsilon_{b}^{\prime}-\varepsilon_{C 4}\right)
\end{aligned}
$$

where $p$ is the percentage of the $C 3$ or $C 4$ grass that is being converted to SRC and $\varepsilon_{b}$ is the base emission rate for the appropriate SRC crop, given in Table 4.

\section{Appendix B}

\section{Determining leaf area index and roughness length}

Scaling factors for the leaf area index and roughness length of the biofuel crops were calculated using the approach outlined above for isoprene emission factors. The values of roughness length $(\sim 0.1 \times$ canopy height $)$ for the relevant plant functional types are given in Table B1. Leaf area index was scaled using relative values of maximum biomass density (i.e. the seasonality of the leaf area index was assumed to be unchanged by the replanting). These values are also shown in Table B1.

Acknowledgements. This work was funded by a NERC studentship to KA and through the QUEST-QUAAC project, NERC grant number NE/C001621/1. GF was supported by the Joint DECC/Defra Met Office Hadley Centre Climate Programme (GA01101). 
Edited by: L. Ganzeveld

\section{References}

Abdullah, A. Z., Salamatinia, B., Mootabadi, H., and Bhatia, S.: Current status and policies on biodiesel industry in Malaysia as the world's leading producer of palm oil, Ener. Pol., 37, 54405448, 2009.

Archibald, A. T., Jenkin, M. E., and Shallcross, D. E.: An isoprene mechanism intercomparison, Atmos. Environ., 44, 5356-5364, 2010.

Archibald, A. T., Levine, J. G., Abraham, N. L., Cooke, M. C., Edwards, P. M., Heard, D. E., Jenkin, M. E., Karunaharan, A., Pike, R. C., Monks, P. S., Shallcross, D. E., Telford, P. J., Whalley, L. K., and Pyle, J. A.: Impacts of $\mathrm{HO}_{\mathrm{x}}$ regeneration and recycling in the oxidation of isoprene: Consequences for the composition of past, present and future atmospheres, Geophys. Res. Lett., 10, L05804, doi:10.1029/2010GL046520, 2011.

Arneth, A., Niinemets, U., Pressley, S., Bäck, J., Hari, P., Karl, T., Noe, S., Prentice, I. C., Serça, D., Hickler, T., Wolf, A., and Smith, B.: Process-based estimates of terrestrial ecosystem isoprene emissions: incorporating the effects of a direct $\mathrm{CO}_{2}$-isoprene interaction, Atmos. Chem. Phys., 7, 31-53, doi:10.5194/acp-7-31-2007, 2007.

Arneth, A., Monson, R. K., Schurgers, G., Niinemets, U., and Palmer, P. I.: Why are estimates of global terrestrial isoprene emissions so similar (and why is this not so for monoterpenes)?, Atmos. Chem. Phys., 8, 4605-4620, doi:10.5194/acp-8-46052008, 2008.

Arneth, A., Schurgers, G., Lathière, J., Duhl, T., Beerling, D. J., Hewitt, C. N., Martin, M., and Guenther, A.: Global terrestrial isoprene emission models: sensitivity to variability in climate and vegetation, Atmos. Chem. Phys., 11, 8037-8052, doi:10.5194/acp-11-8037-2011, 2011.

Atkinson, R. and Arey, J.: Gas-phase tropospheric chemistry of biogenic volatile organic compounds: a review, Atmos. Environ., 37, S197-S219, suppl. 2, 2003.

Bartle, J. R. and Abadi, A.: Toward Sustainable Production of Second Generation Bioenergy Feedstocks, Energy \& Fuels, 24, 2-9, 2010.

Bathiany, S., Claussen, M., Brovkin, V., Raddatz, T., and Gayler, V.: Combined biogeophysical and biogeochemical effects of largescale forest cover changes in the MPI earth system model, Biogeosciences, 7, 1383-1399, doi:10.5194/bg-7-1383-2010, 2010.

Betts, R. A., Falloon, P. D., Goldewijk, K. K., and Ramankutty, N.: Biogeophysical effects of land use on climate: Model simulations of radiative forcing and large-scale temperature change, Agr. Forest Meteorol., 142, 216-233, 2007.

Campbell, J. E., Lobell, D. B., Genova, R. C., and Field, C. B.: The global potential of bioenergy on abandoned agricultural lands, Environ. Sci. Technol., 42, 5791-5794, doi:10.1021/es800052w, 2008.

Carslaw, K. S., Boucher, O., Spracklen, D. V., Mann, G. W., Rae, J. G. L., Woodward, S., and Kulmala, M.: A review of natural aerosol interactions and feedbacks within the Earth system, Atmos. Chem. Phys., 10, 1701-1737, doi:10.5194/acp-10-17012010, 2010.

Chen, J., Avise, J., Guenther, A., Wiedinmyer, C., Salathe, E., Jackson, R. B., and Lamb, B.: Future land use and land cover influences on regional biogenic emissions and air quality in the United States, Atmos. Environ., 36, 5771-5780, doi:10.1016/j.atmosenv.2009.08.015, 2009.

da Costa, R. C.: Potential for producing bio-fuel in the Amazon deforested areas, Biomass Bioener., 26, 405-415, 2004.

Davin, E. L., de Noblet-Decoudré, N., and Friedlingstein, P.: Impact of land cover change on surface climate:Relevance of the radiative forcing concept, Geophys. Res. Lett., 34, L13702, doi:10.1029/2007GL029678, 2007.

Delire, C., Behling, P., Coe, M. T., Foley, J. A., Jacob, R., Kutzbach, J., Liu, Z. Y., and Vavrus, S.: Simulated response of the atmosphere-ocean system to deforestation in the Indonesian Archipelago, Geophys. Res. Lett., 28, 2081-2084, 2001.

Derwent, R. G., Collins, W. J., Jenkin, M. E., Johnson, C. E., and Stevenson, D. S.: The Global Distribution of Secondary Particulate Matter in a 3-D Lagrangian Chemistry Transport Model, J. Atmos. Chem., 44, 57-95, 2003.

Duncan, B. N. and Bey, I.: A modeling study of the export pathways of pollution from Europe: Seasonal and interannual variations (1987-1997), J. Geophys. Res.-Atmos., 109, D08301, doi:10.1029/2003JD004079, 2004.

EC, 2008: Directive 2008/28/EC - on the promotion of the use of energy from renewable sources, commission of the European Communities: Brussels, Belgium. available online at: http://ec. europa.eu/energy/renewables/biofuels/biofuels_en.htm, 2008.

Energy Information Agency, 2010: International Energy Outlook 2010: Chapter 1. World energy demand and economic outlook, United States Energy Information Administration, available online from http://www.eia.doe.gov/oiaf/ieo/, 2010.

FAO, 2006: Fertilizer use by crop, Food and Agricultural Organization of the United Nations, Rome, Italy, available to download from: http://www.fao.org/ag/agl/fertistat/fst_pubs_en.htm, 2006.

Fargione, J., Hill, J., Tilman, D., Polasky, S., and Hawthorne, P.: Land clearing and the biofuel carbon debt, Science, 319, 12351238, 2008.

Fiore, A. M., Dentener, F. J., Wild, O., Cuvelier, C., Schultz, M. G., Hess, P., Textor, C., Schulz, M., Doherty, R. M., Horowitz, L. W., MacKenzie, I. A., Sanderson, M. G., Shindell, D. T., Stevenson, D. S., Szopa, S., Van Dingenen, R., Zeng, G., Atherton, C., Bergmann, D., Bey, I., Carmichael, G., Collins, W. J., Duncan, B. N., Faluvegi, G., Folberth, G., Gauss, M., Gong, S., Hauglustaine, D., Holloway, T., Isaksen, I. S. A., Jacob, D. J., Jonson, J. E., Kaminski, J. W., Keating, T. J., Lupu, A., Marmer, E., Montanaro, V., Park, R. J., Pitari, G., Pringle, K. J., Pyle, J. A., Schroeder, S., Vivanco, M. G., Wind, P., Wojcik, G., $\mathrm{Wu}$, S., and Zuber, A.: Multimodel estimates of intercontinental source-receptor relationships for ozone pollution, J. Geophys. Res.-Atmos., 114, D04301, doi:10.1029/2008JD010816, 2009.

Fischer, G., Prieler, S., van Velthuizen, H., Berndes, G., Faaij, A., Londo, M., and de Wit, M.: Biofuel production potentials in Europe: Sustainable use of cultivated land and pastures, Part II: Land use scenarios, Biomass Bioener., 34, 173-187, 2010.

Folberth, G., Hauglustaine, D. A., Lathière, J., and Brocheton, F.: Interactive chemistry in the Laboratoire de Meteorologie Dynamique general circulation model: model description and impact analysis of biogenic hydrocarbons on tropospheric chemistry, Atmos. Chem. Phys., 6, 2273-2319, doi:10.5194/acp-62273-2006, 2006.

Forster, P., Ramaswamy, V., Artaxo, P., Berntsen, T., Betts, R., Fa- 
hey, D., Haywood, J., Lean, J., Lowe, D., Myhre, G., Nganga, J., Prinn, R., Raga, G., Schulz, M., and R., V. D.: Changes in Atmospheric Constituents and in Radiative Forcing, in: Climate Change 2007: The Physical Science Basis. Contribution of Working Group I to the Fourth Assessment Report of the Intergovernmental Panel on Climate Change, Cambridge University Press, edited by: Solomon, S., Qin, D., Manning, M., Chen, Z., Marquis, M., Averyt, K. B., Tignor, M., and Miller, H. L., 2007.

Ganzeveld, L. and Lelieveld, J.: Impact of Amazonian deforestation on atmospheric chemistry, Geophys. Res. Lett., 31, L06105, doi:10.1029/2003GL019205, 2004.

Ganzeveld, L., Bouwman, L., Stehfest, E., van Vuuren, D. P., Eickhout, B., and Lelieveld, J.: Impact of future land use and land cover changes on atmospheric chemistryclimate interactions, J. Geophys. Res.-Atmos., 115, D233301, doi:10.1029/2010JD014041, 2010.

Garcia-Carreras, L., Parker, D. J., Taylor, C. M., Reeves, C. E., and Murphy, J. G.: Impact of mesoscale vegetation heterogeneities on the dynamical and thermodynamic properties of the planetary boundary layer, J. Geophys. Res.-Atmos., 115, D03102 doi:10.1029/2009JD012811, 2010.

Guenther, A., Hewitt, C. N., Erickson, D., Fall, R., Geron, C., Graedel, T., Harley, P., Klinger, L., Lerdau, M., McKay, W. A., Pierce, T., Scholes, B., Steinbrecher, R., Tallamraju, R., Taylor, J., and Zimmerman, P.: A global-model of natural volatile organic-compound emissions, J. Geophys. Res.-Atmos., 100, 8873-8892, 1995.

Guenther, A., Karl, T., Harley, P., Wiedinmyer, C., Palmer, P. I., and Geron, C.: Estimates of global terrestrial isoprene emissions using MEGAN (Model of Emissions of Gases and Aerosols from Nature), Atmos. Chem. Phys., 6, 3181-3210, doi:10.5194/acp-63181-2006, 2006.

Hallquist, M., Wenger, J. C., Baltensperger, U., Rudich, Y., Simpson, D., Claeys, M., Dommen, J., Donahue, N. M., George, C., Goldstein, A. H., Hamilton, J. F., Herrmann, H., Hoffmann, T., Iinuma, Y., Jang, M., Jenkin, M. E., Jimenez, J. L., KiendlerScharr, A., Maenhaut, W., McFiggans, G., Mentel, T. F., Monod, A., Prevot, A. S. H., Seinfeld, J. H., Surratt, J. D., Szmigielski, R., and Wildt, J.: The formation, properties and impact of secondary organic aerosol: current and emerging issues, Atmos. Chem. Phys., 9, 5155-5236, doi:10.5194/acp-9-5155-2009, 2009.

Heald, C. L., Jacob, D. J., Park, R. J., Russell, L. M., Huebert, B. J., Seinfeld, J. H., Liao, H., and Weber, R. J.: A large organic aerosol source in the free troposphere missing from current models, Geophys. Res. Lett., 32, L18809, doi:10.1029/2005GL023831, 2005.

Heald, C. L., Henze, D. K., Horowitz, L. W., Feddema, J., Lamarque, J.-F., Guenther, A., Hess, P. G., Vitt, F., Seinfeld, J. H., Goldstein, A. H., and Fung, I.: Predicted change in global secondary organic aerosol concentrations in response to future climate, emissions, and land use change, J. Geophys. Res.-Atmos., 113, D05211, doi:10.1029/2007JD009092, 2008.

Hewitt, C. N., MacKenzie, A. R., Di Carlo, P., Di Marco, C. F., Dorsey, J. R., Evans, M., Fowler, D., Gallagher, M. W., Hopkins, J. R., Jones, C. E., Langford, B., Lee, J. D., Lewis, A. C., Lim, S. F., McQuaid, J., Misztal, P., Moller, S. J., Monks, P. S., Nemitz, E., Oram, D. E., Owen, S. M., Phillips, G. J., Pugh, T. A. M., Pyle, J. A., Reeves, C. E., Ryder, J., Siong, J., Skiba, U., and Stewart, D. J.: Nitrogen management is essential to prevent tropical oil palm plantations from causing ground-level ozone pollution, Proc. Natl. Acad. Sci. USA, 106, 18447-18451, 2009.

Hewitt, C. N., Lee, J. D., MacKenzie, A. R., Barkley, M. P., Carslaw, N., Carver, G. D., Chappell, N. A., Coe, H., Collier, C., Commane, R., Davies, F., Davison, B., Di Carlo, P., Di Marco, C. F., Dorsey, J. R., Edwards, P. M., Evans, M. J., Fowler, D., Furneaux, K. L., Gallagher, M., Guenther, A., Heard, D. E., Helfter, C., Hopkins, J., Ingham, T., Irwin, M., Jones, C., Karunaharan, A., Langford, B., Lewis, A. C., Lim, S. F., MacDonald, S. M., Mahajan, A. S., Malpass, S., McFiggans, G., Mills, G., Misztal, P., Moller, S., Monks, P. S., Nemitz, E., Nicolas-Perea, V., Oetjen, H., Oram, D. E., Palmer, P. I., Phillips, G. J., Pike, R., Plane, J. M. C., Pugh, T., Pyle, J. A., Reeves, C. E., Robinson, N. H., Stewart, D., Stone, D., Whalley, L. K., and Yin, X.: Overview: oxidant and particle photochemical processes above a south-east Asian tropical rainforest (the OP3 project): introduction, rationale, location characteristics and tools, Atmos. Chem. Phys., 10, 169-199, doi:10.5194/acp-10169-2010, 2010.

Hill, J., Polasky, S., Nelson, E., Tilman, D., Huo, H., Ludwig, L., Neumann, J., Zheng, H. C., and Bonta, D.: Climate change and health costs of air emissions from biofuels and gasoline, Proc. Natl. Acad. Sci. USA, 106, 2077-2082, 2009.

IEA, 2006: World Energy Outlook: 2004, International Energy Agency, ISBN: 978-92-64-10817-3, 2006.

Ito, A., Sillman, S., and Penner, J. E.: Global chemical transport model study of ozone response to changes in chemical kinetics and biogenic volatile organic compounds emissions due to increasing temperatures: Sensitivities to isoprene nitrate chemistry and grid resolution, J. Geophys. Res.-Atmos., 114, D09301, doi:10.1029/2008JD011254, 2009.

Jardine, K., Serrano, A. Y., Arneth, A., Abrell, L., Jardine, A., van Haren, J., Artaxo, P., Rizzo, L. V., Ishida, F. Y., Karl, T., Kesselmeier, J., Saleska, S., and Huxman, T.: Within-canopy sesquiterpene ozonolysis in Amazonia, J. Geophys. Res.-Atmos., 116, D19301, doi:10.1029/2011JD016243, 2011.

Jimenez, J. L., Canagaratna, M. R., Donahue, N. M., Prevot, A. S. H., Zhang, Q., Kroll, J. H., DeCarlo, P. F., Allan, J. D., Coe, H., Ng, N. L., Aiken, A. C., Docherty, K. S., Ulbrich, I. M., Grieshop, A. P., Robinson, A. L., Duplissy, J., Smith, J. D., Wilson, K. R., Lanz, V. A., Hueglin, C., Sun, Y. L., Tian, J., Laaksonen, A., Raatikainen, T., Rautiainen, J., Vaattovaara, P., Ehn, M., Kulmala, M., Tomlinson, J. M., Collins, D. R., Cubison, M. J., Dunlea, E. J., Huffman, J. A., Onasch, T. B., Alfarra, M. R., Williams, P. I., Bower, K., Kondo, Y., Schneider, J., Drewnick, F., Borrmann, S., Weimer, S., Demerjian, K., Salcedo, D., Cottrell, L., Griffin, R., Takami, A., Miyoshi, T., Hatakeyama, S., Shimono, A., Sun, J. Y., Zhang, Y. M., Dzepina, K., Kimmel, J. R., Sueper, D., Jayne, J. T., Herndon, S. C., Trimborn, A. M., Williams, L. R., Wood, E. C., Middlebrook, A. M., Kolb, C. E., Baltensperger, U., and Worsnop, D. R.: Evolution of organic aerosols in the atmosphere, Science, 326, 1525-1529, 2009.

Jones, C. D., Hughes, J. K., Bellouin, N., Hardiman, S. C., Jones, G. S., Knight, J., Liddicoat, S., O’Connor, F. M., Andres, R. J., Bell, C., Boo, K.-O., Bozzo, A., Butchart, N., Cadule, P., Corbin, K. D., Doutriaux-Boucher, M., Friedlingstein, P., Gornall, J., Gray, L., Halloran, P. R., Hurtt, G., Ingram, W., Lamarque, J.-F., Law, R. M., Meinshausen, M., Osprey, S., Palin, 
E. J., Chini, L. P., Raddatz, T., Sanderson, M., Sellar, A. A., Schurer, A., Valdes, P., Wood, N., Woodward, S., Yoshioka, M., and Zerroukat, M.: The HadGEM2-ES implementation of CMIP5 centennial simulations, Geosci. Model Dev., 4, 543-570, doi:10.5194/gmd-4-543-2011, 2011.

Kiendler-Scharr, A., Wildt, J., Dal Maso, M., Hohaus, T., Kleist, E., Mentel, T. F., Tillmann, R., Uerlings, R., Schurr, U., and Wahner, A.: New particle formation in forests inhibited by isoprene emissions, Nature, 461, 381-384, 2009.

Koh, L. P., Levang, P., and Ghazoul, J.: Designer landscapes for sustainable biofuels, Trends Ecol. Evol., 24, 431-438, 2009.

Lamarque, J. F., Bond, T. C., Eyring, V., Granier, C., Heil, A., Klimont, Z., Lee, D., Liousse, C., Mieville, A., Owen, B., Schultz, M. G., Shindell, D., Smith, S. J., Stehfest, E., Van Aardenne, J., Cooper, O. R., Kainuma, M., Mahowald, N., McConnell, J. R., Naik, V., Riahi, K., and van Vuuren, D. P.: Historical (1850-2000) gridded anthropogenic and biomass burning emissions of reactive gases and aerosols: methodology and application, Atmos. Chem. Phys., 10, 7017-7039, doi:10.5194/acp10-7017-2010, 2010.

Langford, B., Misztal, P. K., Nemitz, E., Davison, B., Helfter, C., Pugh, T. A. M., MacKenzie, A. R., Lim, S. F., and Hewitt, C. N.: Fluxes and concentrations of volatile organic compounds from a South-East Asian tropical rainforest, Atmos. Chem. Phys., 10, 8391-8412, doi:10.5194/acp-10-8391-2010, 2010.

Lathière, J., Hauglustaine, D. A., Friend, A. D., De NobletDucoudré, N., Viovy, N., and Folberth, G. A.: Impact of climate variability and land use changes on global biogenic volatile organic compound emissions, Atmos. Chem. Phys., 6, 2129-2146, doi:10.5194/acp-6-2129-2006, 2006.

Lee, A., Goldstein, A. H., Kroll, J. H., Ng, N. L., Varutbangkul, V., Flagan, R., and Seinfeld, J.: Gas-phase products and secondary organic aerosol yields from the photooxidation of 16 different terpenes, J. Geophys. Res.-Atmos., 111, D17305, doi:10.1029/2006JD007050, 2006.

Lelieveld, J., Butler, T. M., Crowley, J. N., Dillon, T. J., Fischer, H., Ganzeveld, L., Harder, H., Lawrence, M. G., Martinez, M., Taraborrelli, D., and Williams, J.: Atmospheric oxidation capacity sustained by a tropical forest, Nature, 452, 737-740, 2008.

Mann, G. W., Carslaw, K. S., Spracklen, D. V., Ridley, D. A., Manktelow, P. T., Chipperfield, M. P., Pickering, S. J., and Johnson, C. E.: Description and evaluation of GLOMAP-mode: a modal global aerosol microphysics model for the UKCA composition-climate model, Geosci. Model Dev., 3, 519-551, doi:10.5194/gmd-3-519-2010, 2010.

Melillo, J. M., Reilly, J. M., Kicklighter, D. W., Gurgel, A. C., Cronin, T. W., Paltsev, S., Felzer, B. S., Wang, X., Sokolov, A. P., and Schlosser, C. A.: Indirect emissions from biofuels: How important?, Science, 326, 1397-1399, 2009.

Menichetti, E. and Otto, M.: Chapter 5: Energy balance and greenhouse gas emissions of biofuels from a life-cycle perspective, in: Biofuels: Environmental consequences and interactions with changing land use, Scientific Committee on Problems of the Environment (SCOPE) International Biofuels Project Rapid Assessment, edited by: Howarth, R. W., and Bringezu, S., ISBN:1441488294, 2009.

Misztal, P. K., Owen, S. M., Guenther, A. B., Rasmussen, R., Geron, C., Harley, P., Phillips, G. J., Ryan, A., Edwards, D. P., Hewitt, C. N., Nemitz, E., Siong, J., Heal, M. R., and Cape, J. N.:
Large estragole fluxes from oil palms in Borneo, Atmos. Chem. Phys., 10, 4343-4358, doi:10.5194/acp-10-4343-2010, 2010.

Misztal, P. K., Nemitz, E., Langford, B., Di Marco, C. F., Phillips, G. J., Hewitt, C. N., MacKenzie, A. R., Owen, S. M., Fowler, D., Heal, M. R., and Cape, J. N.: Direct ecosystem fluxes of volatile organic compounds from oil palms in South-East Asia, Atmos. Chem. Phys., 11, 8995-9017, doi:10.5194/acp-11-89952011, 2011.

Müller, J.-F., Stavrakou, T., Wallens, S., De Smedt, I., Van Roozendael, M., Potosnak, M. J., Rinne, J., Munger, B., Goldstein, A., and Guenther, A. B.: Global isoprene emissions estimated using MEGAN, ECMWF analyses and a detailed canopy environment model, Atmos. Chem. Phys., 8, 1329-1341, doi:10.5194/acp-81329-2008, 2008.

Nakicenovic, N. and Swart, R., eds.: Special Report on Emissions Scenarios: A special report of Working Group III of the Intergovernmental Panel on Climate Change, Cambridge University Press, ISBN:0-521-80081-1, 978-052180081-5, 2000.

Ou, X. M., Zhang, X. L., Chang, S. Y., and Guo, Q. F.: Energy consumption and GHG emissions of six biofuel pathways by LCA in (the) People's Republic of China, Appl. Ener., 86, S197-S208, suppl. 1, 2009.

Pacifico, F., Harrison, S. P., Jones, C. D., Arneth, A., Sitch, S., Weedon, G. P., Barkley, M. P., Palmer, P. I., Serca, D., Potosnak, M., Fu, T.-M., Goldstein, A., Bai, J., and Schurgers, G.: Evaluation of a photosynthesis-based biogenic isoprene emission scheme in JULES and simulation of isoprene emissions under present-day climate conditions, Atmos. Chem. Phys., 11, 43714389, doi:10.5194/acp-11-4371-2011, 2011.

Penner, J., Andreae, M., Annegarn, H., Barrie, L., Feichter, J., Hegg, D., Jayaraman, A., Leaitch, R., Murphy, D., Nganga, J., and Pitari, G.: Aerosols, their direct and indirect effects, in: Climate Change 2001. The Scientific Basis. Contribution of Working Group I to the Third Assessment Report of the Intergovernmental Panel on Climate Change, Cambridge University Press, edited by: Houghton, J. T., Ding, Y., Griggs, D. J., Noguer, M., van der Linden, P. J., Dai, X., Maskell, K., and Johnson, C. A., 238-287, 2001.

Perlack, R. D., Wright, L. L., Turhollow, A. F., Graham, R. L., Stokes, B. J., and Erbach, D. C.: Biomass as feedstock for a bioenergy and bioproducts industry: The technical feasibility of a billion-ton annual supply, Tech. rep., United States Department of Agriculture and United States Department of Energy, http:// feedstockreview.ornl.gov/pdf/billion_ton_vision.pdf, last access: April 2011, 2005.

Pleanjai, S. and Gheewala, S. H.: Full chain energy analysis of biodiesel production from palm oil in Thailand, Applied Energy, 86, S209-S214, suppl. 1, 2009.

Pöschl, U., von Kuhlmann, R., Poisson, N., and Crutzen, P. J.: Development and intercomparison of condensed isoprene oxidation mechanisms for global atmospheric modeling, J. Atmos. Chem., 37, 29-52, 2000.

Pugh, T. A. M., MacKenzie, A. R., Hewitt, C. N., Langford, B., Edwards, P. M., Furneaux, K. L., Heard, D. E., Hopkins, J. R., Jones, C. E., Karunaharan, A., Lee, J., Mills, G., Misztal, P., Moller, S., Monks, P. S., and Whalley, L. K.: Simulating atmospheric composition over a South-East Asian tropical rainforest: performance of a chemistry box model, Atmos. Chem. Phys., 10, 279-298, doi:10.5194/acp-10-279-2010, 2010. 
Pyle, J. A., Warwick, N. J., Harris, N. R. P., Abas, M. R., Archibald, A. T., Ashfold, M. J., Ashworth, K., Barkley, M. P., Carver, G. D., Chance, K., Dorsey, J., Fowler, D., Gonzi, S., Gostlow, B., Hewitt, C. N., Kurosu, T. P., Lee, J. D., Langford, B., Mills, G., Moller, S., MacKenzie, A. R., J., M. A., Misztal, P., Nadzir, M. S. M., Nemitz, E., Newton, H., O’Brien, L. M., Ong, S., Oram, D., Palmer, P. I., Peng, L. K., Phang, S. M., Pike, R., Pugh, T. A. M., Rahman, N. A., Robinson, A. D., Samah, A. A., Sentian, J., Skiba, U., Ung, H. E., Yong, S. E., and Young, P.: The impact of local surface processes in Borneo on atmospheric composition at wider spatial scales: coastal processes, land use change and air quality, Phil. Trans. Roy. Soc. Lnd., 366, 3210-3224, 2011.

Reijnders, L. and Huijbregts, M. A. J.: Palm oil and the emission of carbon-based greenhouse gases, J. Clean. Prod., 16, 477-482, 2008.

Royal Society, 2008: Ground-level ozone in the 21st century: future trends, impacts and policy implications, Science Policy Report 15/08, edited by: Fowler, D., 2008.

Royal Society, 2008: Sustainable biofuels: Prospects and challenges, Science Policy Report 01/08, edited by: Pickett, J., 2008.

Ruuskanen, T. M., Mueller, M., Schnitzhofer, R., Karl, T., Graus, M., Bamberger, I., Hortnagl, L., Brilli, F., Wohlfahrt, G., and Hansel, A.: Eddy covariance VOC emission and deposition fluxes above grassland using PTR-TOF, Atmos. Chem. Phys., 11, 611-625, doi:10.5194/acp-11-611-2011, 2011.

Sakulyanontvittaya, T., Duhl, T., Wiedinmyer, C., Helmig, D.and Matsunaga, S., Potosnak, M., Milford, J., and Guenther, A.: Monoterpene and sesquiterpene emission estimates for the United States, Environ. Sci. Technol., 42, 1623-1629, doi:10.1021/es702274e, 2008.

Schneck, R. and Mosbrugger, V.: Simulated climate effects of Southeast Asian deforestation: Regional processes and teleconnection mechanisms, J. Geophys. Res.-Atmos., 116, D11116 doi:10.1029/2010JD015450, 2011.

Searchinger, T., Heimlich, R., Houghton, R. A., Dong, F. X., Elobeid, A., Fabiosa, J., Tokgoz, S., Hayes, D., and Yu, T. H.: Use of US croplands for biofuels increases greenhouse gases through emissions from land-use change, Science, 319, 12381240, 2008

Sillman, S.: The relation between ozone, NOx and hydrocarbons in urban and polluted rural environments, Atmos. Environ., 33, 1821-1845, 1999.

Simpson, D., Guenther, A., Hewitt, C. N., and Steinbrecher, R.: Biogenic emissions in Europe. 1. Estimates and uncertainties, J. Geophys. Res.-Atmos., 100, 22875-22890, doi:10.1029/95JD02368, 1995.

Spracklen, D. V., Carslaw, K. S., Kulmala, M., Kerminen, V. M., Mann, G. W., and Sihto, S. L.: The contribution of boundary layer nucleation events to total particle concentrations on regional and global scales, Atmos. Chem. Phys., 6, 5631-5648, doi:10.5194/acp-6-5631-2006, 2006.

Spracklen, D. V., Jimenez, J. L., Carslaw, K. S., Worsnop, D. R., Evans, M. J., Mann, G. W., Zhang, Q., Canagaratna, M. R., Allan, J., Coe, H., McFiggans, G., Rap, A., and Forster, P.: Aerosol mass spectrometer constraint on the global secondary organic aerosol budget, Atmos. Chem. Phys., 11, 12109-12136, doi:10.5194/acp-11-12109-2011, 2011.

Stavrakou, T., Müller, J.-F., De Smedt, I., Van Roozendael, M., van der Werf, G. R., , Giglio, L., and Guenther, A.: Evaluating the performance of pyrogenic and biogenic emission inventories against one decade of space-based formaldehyde columns, Atmos. Chem. Phys., 9, 1037-1060, doi:10.5194/acp-9-1037-2009, 2009.

Stavrakou, T., Guenther, A., Razavi, A., Clarisse, L., Clerbaux, C., Coheur, P., Hurtmans, D., Karagulian, F., De Maziere, M., Vigouroux, C., Amelynck, C., Schoon, N., Laffineur, Q., Heinesch, B., Aubinet, M., Rinsland, C., and Müller, J.-F.: First space-based derivation of the global atmospheric methanol emission fluxes, Atmos. Chem. Phys., 11, 4873-4898, doi:10.5194/acp-11-4873-2011, 2011.

Steiner, A. L., Tonse, S., Cohen, R. C., Goldstein, A. H., and Harley, R. A.: Biogenic 2-methyl-3-buten-2-ol increases regional ozone and $\mathrm{HO}_{\mathrm{x}}$ sources, Geophys. Res. Lett., 34, L15806, doi:10.1029/2007GL030802, 2007.

Streets, D. G., Bond, T. C., Carmichael, G. R., Fernandes, S. D., Fu, Q., He, D., Klimont, Z., Nelson, S. M., Tsai, N. Y., Wang, M. Q., Woo, J. H., and Yarber, K. F.: An inventory of gaseous and primary aerosol emissions in Asia in the year 2000, J. Geophys. Res.-Atmos., 108, D218809, doi:10.1029/2002JD003093, 2003.

Thoenes, P.: Biofuels and Commodity Markets - Palm Oil Focus, Tech. rep., Commodities and Trade Division, United Nations Food and Agriculture Organization, http://www.fao.org/es/esc/ en/15/120/124/highlight_629.html, last access: April 2011, 2007.

Tie, X., Guenther, A., and Holland, E.: Biogenic methanol and its impact on tropospheric oxidants, Geophys. Res. Lett., 30, L171881, doi:10.1029/2003GL017167, 2003.

Tsigaridis, K. and Kanakidou, M.: Secondary organic aerosol importance in the future atmosphere, Atmos. Environ., 41, 46824692, 2007.

USDA, 2009: USDA Foreign Agricultural Service Commodity Intelligence Report: Indonesia: Palm oil production growth to continue, http://www.pecad.fas.usda.gov/highlights/2009/03/ Indonesia, last access: April 2011, 2009.

von Kuhlmann, R., Lawrence, M., Pöschl, U., and Crutzen, P.: Sensitivities in global scale modeling of isoprene, Atmos. Chem. Phys., 4, 1-17, doi:10.5194/acp-4-1-2004, 2004.

Went, F. W.: Blue hazes in the atmosphere, Nature, 187, 641-643, 1960.

Wesely, M. L.: Parameterization of surface resistances to gaseous dry deposition in regional-scale numerical models, Atmos. Environ., 23, 1293-1304, 1989.

WHO, 2005: Air quality guidelines - global update 2005, http //www.who.int/phe/health_topics/outdoorair_aqg/en/index.html, 2005.

Wiedinmyer, C., Tie, X. X., Guenther, A., Neilson, R., and Granier, C.: Future changes in biogenic isoprene emissions: How might they affect regional and global atmospheric chemistry?, Earth Interactions, 10, international Young Scientists Global Change Conference 2003, 16-19 November 2003, Trieste, Italy, 2006.

Wild, O.: Modelling the global tropospheric ozone budget: exploring the variability in current models, Atmos. Chem. Phys., 7 , 2643-2660, doi:10.5194/acp-7-2643-2007, 2007.

Wild, O., Sundet, J. K., Prather, M. J., Isaksen, I. S. A., Akimoto, H., Browell, E. V., and Oltmans, S. J.: Chemical transport model ozone simulations for spring 2001 over the western Pacific: Comparisons with TRACE-P lidar, ozonesondes, and Total Ozone Mapping Spectrometer columns, J. Geophys. Res.Atmos., 108, D218826 doi:10.1029/2002JD003283, 2003. 
Zhang, Q., Jimenez, J. L., Canagaratna, M. R., Allan, J. D., Coe, H., Ulbrich, I., Alfarra, M. R., Takami, A., Middlebrook, A. M., Sun, Y. L., Dzepina, K., Dunlea, E., Docherty, K., DeCarlo, P. F., Salcedo, D., Onasch, T., Jayne, J. T., Miyoshi, T., Shimono, A., Hatakeyama, S., Takegawa, N., Kondo, Y., Schneider, J., Drewnick, F., Borrmann, S., Weimer, S., Demerjian, K., Williams, P., Bower, K., Bahreini, R., Cottrell, L., Griffin, R. J., Rautiainen, J., Sun, J. Y., Zhang, Y. M., and Worsnop, D. R.: Ubiquity and dominance of oxygenated species in organic aerosols in anthropogenically-influenced Northern Hemisphere midlatitudes, Geophys. Res. Lett., 34, L13801, doi:10.1029/2007GL029979, 2007.
Zhou, A. and Thomson, E.: The development of biofuels in Asia, Applied Energy, 86, S11-S20, suppl. 1, 2009. 